\title{
Political Agreements and Exporting Activities: An Empirical Assessment of the Effects of the JCPOA Agreement on Iran's Exports
}

\author{
Ali Dadpay* \\ University of Dallas \\ Saleh S. Tabrizy \\ The University of Oklahoma
}

August 2020

\begin{abstract}
Conflicts hinder international trade. Political agreements that restrain conflicts and remove sanctions may contribute positively to exporting and importing activities. In this study, we examine the effects of the Joint Comprehensive Plan of Action, commonly known as Iran Nuclear Deal, on Iran's non-oil exports. Employing a dynamic panel model, we find a significant increase in the growth rate of industry-level exports following the removal of nuclear-related sanctions, resulting from this political agreement. In particular, the exports of industries that have relatively low shares in Iran's non-oil exports grow significantly faster than industries with relatively high shares in those exports. Our findings suggest that even a short-lived political agreement could have significant positive effects on exporting activities in middle income countries.
\end{abstract}

Keywords: Political Agreements; Sanctions; Exports; Iran; JCPOA

JEL Classifications: F14; F5

\footnotetext{
${ }^{*}$ Corresponding author. Email: adadpay@udallas.edu; Phone: (972) 721-4072.

The authors would like to thank an anonymous referee and seminar participants at the Global Strategy and Emerging Markets Conference at University of Texas at Dallas (2019), Southern Economic Association Conference (2019), and the Middle East Economic Association Conference at ASSA Meetings (2020) for their helpful comments.
} 


\section{Introduction}

International exchanges of goods and services do not occur in a vacuum. Political and trade agreements accommodate such transactions. In particular, by restraining conflicts, political agreements may contribute positively to trade, as there is ample evidence suggesting that conflicts may hinder international trade in goods and services. For example, Blomberg and Hess (2006) and Glick and Taylor (2010) examine historical data showing that conflicts may adversely affect international trade as well as national income and global welfare. ${ }^{1}$ Beyond the adverse effects on merchandise trade, Didier (2020) suggests that conflicts may negatively impact trade in financial and travel services. Plus, conflicts appear to have some spillover effects. For example, Qureshi (2013) finds that internal or external conflicts in contiguous countries have persistent adverse effects on neighboring countries who may not even be involved in any disputes. Pham and Doucouliagos (2017) and De Sousa, Mirza, and Verdier (2018) offer more evidence for such spillover effects. ${ }^{2}$

Along with the potential for restraining conflicts, political agreements may also lead to the removal of trade barriers, including international sanctions. In return, they may contribute positively to trade in goods and services. Several studies have already examined the adverse effects of sanctions on trade; examples include Caruso (2003), Yang et al. (2004), and Felbermayr et al. (2019). These studies suggest that sanctions negatively affect international trade, though their ultimate impacts may vary significantly. Considering the adverse effects of sanctions on trade, we expect that sanctions removal may contribute positively to trade. But there are only a few studies that examine this channel.

\footnotetext{
${ }^{1}$ Blomberg and Hess (2006) suggest that the tariff-equivalent cost of terrorism together with internal and external conflicts may amount to a $30 \%$ tariff rate, which is greater than the trade cost imposed by borders and language barriers.

${ }^{2}$ There is another strand of trade literature that focus on the effects of regional trade agreements on conflicts. Examples include Hegre, Oneal, and Russett (2010), Vicard (2012), and Seitz, Tarasov, and Zakharenko (2015). Further, there are few other studies in which conflicts and trade are both considered as endogenous. For instance, Martin, Mayer, and Thoenig (2008) show that even though greater bilateral trade may lower the probability of escalations, countries that are relatively more engaged in global trade are more likely to engage in bilateral conflicts as their multilateral trade relation decreases their bilateral dependency. Also, Martin, Mayer, and Thoenig (2012) suggest that countries that are likely to gain from regional trade agreements and, at the same time, are likely to be involved in bilateral conflicts are more likely to sign a regional trade agreement. Using this complementarity, they are able to determine the geography of regional trade agreements.
} 
In this paper, we examine the trade effects of the Joint Comprehensive Plan of Action (henceforth, JCPOA), reached on July 2015 between Iran, China, France, Germany, Russia, the U.K., and the U.S. (i.e., the permanent members of the U.N. Security Council, plus Germany). This political agreement successfully restrained the potential for a new conflict in the Middle East. It also led to the removal of an array of nuclear-related sanctions against Iran. Sanctions relief did not last long, however, as the U.S. terminated its participation in the JCPOA agreement in May 2018. Nevertheless, this shortlived agreement provides a rare opportunity for us to study how restraining conflicts and sanctions removal may affect trade.

We exclude crude oil exports, focusing on Iran's non-oil exporting activities. As described more fully in Section 3, the JCPOA agreement led to a significant recovery of Iran's oil exports. This positive effect is plain to see. Yet, the impact on non-oil exports has remained unexplored. Plus, as shown in Figure 1, non-oil exports have increasingly become more important in Iran's current account. Ever since 2012, more than $30 \%$ of Iran's exports are comprised of non-oil products, which may, in part, be the result of intensified sanctions that hampered oil exports. Further, as Haidar (2017) argues, the private sector in Iran has engaged more actively in non-oil exports when compared to oil exports, which are dominated by the state and semi-governmental entities. Also, those exports are likely to make greater contributions to employment, as opposed to highly capital-intensive oil exports.

We explore quarterly trade data for a panel of 28 industries in the manufacturing, mining, and agriculture sectors. The time series of the panel begins as of March 2011 and ends in March 2018. It provides an array of observations before and after the JCPOA agreement, enabling us to draw an informed comparison.

Following the empirical approach in Santos-Paulino (2002), Santos-Paulino and Thirlwall (2004), and Ratnaike (2012), we employ canonical dynamic panel data estimation techniques to study the effect of sanctions removal on export growth. Our estimations results suggest that the growth rate of Iran's nonoil exports is significantly higher after the JCPOA agreement when compared with a similar window of time before the settlement. Conditional upon a wide range of covariates, including the initial value of 
exports and lagged growth rates, we find that on average industry-level exports grow $9.9 \%$ faster

following the JCPOA agreement. ${ }^{3}$ This positive effect is also evident when we employ an ordinal measure based on the timing of the nuclear negotiations and the interim deal that ultimately led to the comprehensive agreement of interest.

We also examine industry-level heterogeneities. We find that the exports of industries that have relatively low shares in Iran's non-oil exports grow significantly faster when compared to industries with relatively high percentages in non-oil exports. We show that the exports of industries with relatively low shares were affected more severely by sanctions. Once sanctions were removed, we observe that their exports grow relatively faster, making up for prior contractions.

Our findings suggest that even a short-lived political agreement could have significant positive effects on exporting activities in middle-income countries, including those who rely heavily on commodity exports. They also suggest that these effects could be of great importance for industries that are not necessarily known as the leading exporting industries in such countries. This finding is in line with the results that are recently reported by Giri, Quayyum, and Yin (2019), who suggest that reducing trade barriers may lead to higher export diversification among commodity exporters.

In Section 2, we review previous studies on the trade effects of sanctions. In Section 3, we describe the background of the JCPOA agreement. In Section 4, we present our empirical analyses by describing our data, empirical approach, and findings. Section 5 concludes our findings and arguments.

\section{Trade Effects of Sanctions}

There are several studies that examine the effects of sanctions on international trade. These studies reveal that sanctions often have significant trade effects, but their ultimate impacts may vary. For instance, multilateral sanctions on exports and imports tend to have significant adverse effects when compared to, say, unilateral sanctions that are not fully imposed, e.g., sanctions that are only threatened or merely imposed on imports.

\footnotetext{
${ }^{3}$ This estimation, as discussed more fully in Section 4, is done for annual growth rates.
} 
Caruso (2003) is among the first to examine the trade effects of sanctions. Exploring the bilateral trade between the U.S. and 49 target countries between 1960 and 2000, he finds that comprehensive multilateral sanctions have large adverse effects on trade flows, while moderate unilateral sanctions may lead to trade deflection. Yang et al. (2004) document similar findings, exploring the data between 1980 and 1998. They offer further evidence for trade deflection, suggesting that the U.S. unilateral comprehensive sanctions increase the trade flow between the target countries and the E.U. or Japan. Further, exploring a detailed sample made of 60 sanctioning countries and 143 targets between 1960 and 2009, Afesorgbor (2019) finds that imposed sanctions lead to a decline in bilateral trade. In contrast, threatened sanctions may lead to an increase in bilateral trade due to stockpiling effects. This effect is, in particular, evident among medicines and pharmaceutical products.

Relying on a newly developed dataset that includes 729 sanction cases between 1950 and 2015, Felbermayr et al. (2019) examine the trade and welfare effects of international sanctions. Similar to the studies above, they find that sanctions have significant but heterogeneous effects. They distinguish, for example, between export vs. import sanctions; they suggest that sanctions that simultaneously target exports and imports and sanctions that merely target exports are more effective when compared to sanctions that merely target imports. They also distinguish between complete vs. partial trade sanctions; they suggest that comprehensive bilateral sanctions are more effective when compared to partial sanctions.

There are also several case studies that exclusively focus on Iran. ${ }^{4}$ Among them, a few rely on computable general equilibrium models with particular implications for trade; examples include Farzanegan et al. (2016) and Gharibnavaz and Waschik (2018). There are also a few studies that focus on partial equilibrium trade effects of sanction. For example, Esfahani and Rasoulinezhad (2017) examine the bilateral trade between Iran and 25 E.U. destinations as well as the bilateral trade between Iran and 25 Asian destinations between 2006 and 2013. They show that sanctions against Iran have led to significant

\footnotetext{
${ }^{4}$ There are other case studies for other countries. Crozet and Hinz (2020) is a recent example, in which the trade effects of sanctions against Russia are examined in detail.
} 
trade deflection, away from the E.U. destinations and towards Asian destinations. Haidar (2017) also finds similar evidence, employing disaggregated firm-level data between 2006 and 2011. He shows that about two-thirds of Iran's non-oil exports, affected by export sanctions, were deflected to non-sanctioning destinations. He further finds that, despite sanctions, firms exporting to non-sanctioning destinations increased their exports; more precisely, they lowered their prices and increased their export quantities. He also observes that large exporters were more likely to deflect their exports and that the majority of deflected exports were of core and homogeneous products.

Felbermayr et al. (2019) present another case study for Iran. Fixing the sanction type, they show that the trade effects of sanctions vary across country pairs (e.g., US-Iran vs. China-Iran) and even within country pairs (e.g., Turkey-Iran vs. Iran-Turkey). Though, in most cases, they find significant adverse trade effects from sanctions; in some cases, they find insignificant or even positive impacts that imply export deflections.

Against this background, our paper examines how the removal of international sanctions, resulting from the JCPOA agreement, contributes to industry-level exporting activities in Iran. As mentioned in Section 1, we limit our study to non-oil exports. To the best of our knowledge, our paper is the first study that directly examines the effects of sanctions relief on Iran's non-oil exports.

The underlying question of our research is motivated by the projections that are reported by Devarajan and Mottaghi (2015) and Felbermayr et al. (2019). Highlighting the significance of trade deflection, Devarajan and Mottaghi (2015) show that sanctions against Iran led to a significant loss of export revenue from 2012 to $2014 .{ }^{5}$ Based on their estimations for the trade effects of sanctions, they propose that sanctions removal may lead to a substantial increase in Iran's oil and non-oil exports.

Stemming from the projected increase in exports, they also estimate a significant welfare gain amounting to a rise of $2.8 \%$ of welfare per capita. ${ }^{6}$ Furthermore, quantifying the general equilibrium effects of

\footnotetext{
${ }^{5}$ They estimate that the loss of oil and non-oil exports revenue during the time period above may amount to $13.5 \%$ of total exports earnings. This loss could be translated to about $4.5 \%$ of Iran's GDP at that time.

${ }^{6}$ Devarajan and Mottaghi (2015) rely on two empirical studies: the estimation for exports effect is based on Mottaghi (2015), and the estimation for welfare effect is based on Ianchovichina, Devarajan, and Lakatos (2016).
} 
sanctions, Felbermayr et al. (2019) entertain a counterfactual without any sanctions on Iran. They show that Iran's economy opens up significantly under this hypothetical scenario. Beyond trade effects, they also estimate a significant national income gain for Iran, amounting to an increase of $4.2 \%$ of real per capita income.

The aforementioned studies suggest that Iran's oil exports benefit significantly from the removal of sanctions, which, in return, generate sizable aggregate effects. When it comes to the JCPOA, this effect is evident in the aggregate time-series wherein oil exports are of great importance (Section 3). Yet, beyond oil exports, it is more interesting to examine the effects of sanctions removals on Iran's non-oil exports. In fact, in their counterfactual analyses, Felbermayr et al. (2019) suggest that there are a number of non-oil industries that are expected to gain from sanctions removal. ${ }^{7}$ Examples include leather, textile, and transportation.

Our paper contributes to this literature by estimating how sanctions removal may, in practice, contribute to the growth of non-oil exports. We employ quarterly, industry-level data (28 industries) before and after the JCPOA agreement (from March 2011 to March 2018). Given that we rely on the frequency of quarterly data, we are unable to employ bilateral trade variations at the industry-level. We instead employ industry-level variations that are aggregated across destinations.

Our findings are in line with the projections that are reported in Devarajan and Mottaghi (2015) and Felbermayr et al. (2019). On average, the removal of sanctions, resulting from the JCPOA agreement, leads to faster growth of non-oil exports. Under sanctions, we observe sizable contractions in the exports of industries that have a relatively low share in Iran's non-oil exports. Given the contractions preceding the agreement, we observe that the exports of industries that have relatively low shares in non-oil exports increase significantly faster than industries with relatively high shares. This suggests that sanctions removal may introduce significant dynamics to the export of industries that are not necessarily known as the leading exporters, improving export diversification.

\footnotetext{
${ }^{7}$ They measure this gain in terms of projected changes in value added.
} 


\section{The JCPOA Agreement}

The JCPOA is a political agreement reached between Iran and the permanent members of the U.N. Security Council, plus Germany, in July 2015. This agreement was implemented to ensure that "Iran's nuclear program will be exclusively peaceful." In return, it was expected to "produce the comprehensive lifting of all U.N. Security Council sanctions as well as multilateral and national sanctions related to Iran's nuclear program, including steps on access in areas of trade, technology, finance, and energy" (U.N. Security Council, 2015).

The JCPOA agreement was the result of an interim agreement, called the Joint Plan of Action (henceforth, JPOA). Under the interim agreement, finalized in November 2013, Iran limited its nuclear program in exchange for initial sanctions relief. More importantly, the participants stated that the ultimate goal of the interim agreement was to "reach a mutually-agreed long-term comprehensive solution that would ensure Iran's nuclear program will be exclusively peaceful [...] and would produce the comprehensive lifting of all U.N. Security Council sanctions, as well as multilateral and national sanctions related to Iran's nuclear program" (Reuters, 2013).

The JPOA agreement set the stage for the JCPOA agreement, which was finalized on July $14^{\text {th }}$, 2015. It was soon endorsed by the U.N. Security Council under UNSC Res. No. 2231 on July $20^{\text {th }}, 2015$. It was implemented on January $16^{\text {th }}, 2016$, when the U.N. Security Council received a report from the International Atomic Energy Agency (henceforth, IAEA), the U.N. nuclear watchdog, confirming that Iran had taken a series of nuclear-related actions as specified in the agreement.

The JCPOA agreement was short-lived. In less than three years, the agreement fell apart when the U.S. terminated its participation on May $18^{\text {th }}, 2018$, which triggered the re-imposition of nuclear-related U.S. sanctions against Iran starting from August $7^{\text {th }}, 2018 .{ }^{8}$ Nonetheless, during its short life, the JCPOA agreement achieved two essential goals: 1.) the IAEA confirmed in January 2016 and in subsequent quarterly reports that Iran was in compliance with the agreement, and 2.) the U.S., the E.U., and the U.N.

\footnotetext{
${ }^{8}$ Refer to United Nation Security Council (2015) and US Department of State (2019) for more detail about the timeline.
} 
repealed or suspended their nuclear-related sanctions following the IAEA report in January 2016 (Council on Foreign Relations, 2019)..$^{9}$ The latter is of importance to this study.

The removal of nuclear-related sanctions, resulting from the JCPOA agreement, led to a significant increase in Iran's real aggregate exports. ${ }^{10}$ Before the interim deal (the JPOA), Iran's exports had plummeted starting from 2011. Preceded by a small decline in 2010, Iran's real aggregate exports dropped from $\$ 118.21$ billion in 2011 to $\$ 85.09$ billion in 2013 (World Bank, 2019a). ${ }^{11}$ This rapid decline was, in part, the result of the sanctions that were put in place by the U.S. and the E.U. against Iran's crude oil exports (Maloney, 2015; pp. 464-473). Measured by quantity, Iran's crude oil exports dropped by more than 50\% from 2.5 million barrels per day in 2011 to 1.2 million barrels per day in 2013; this decline persisted until 2015, during which crude exports were recorded at 1.1 million barrels per day. By 2017, thanks to the JCPOA agreement, Iran was exporting 2.1 million barrels of crude oil per day (OPEC, 2019a). It was a relatively low level of crude exports for post-war Iran. Yet, it was a significant recovery. As a result, despite relatively low prices, the nominal value of Iran's oil exports in 2017 reached $\$ 52.72$ billion (OPEC, 2019b). ${ }^{12}$

Driven in part by the increase in crude oil exports, Iran's aggregate exports were recovered following the JPOA and JCPOA agreements. By 2017, Iran's real aggregate exports exceeded \$147 billion, the highest aggregate value observed in post-war Iran. ${ }^{13}$ This increase was, in fact, preceded by an earlier adjustment started in 2014. Iran's real aggregate exports had initially increased from $\$ 85.05$ billion in 2013 (the lowest aggregate value observed since 1991) to $\$ 91.18$ billion in 2014. From there, it grew to an unprecedented level observed in 2017 (World Bank, 2019a). After a significant decline, aggregate imports also recovered slightly following the JCPOA agreement. While Iran's aggregate imports had

\footnotetext{
${ }^{9}$ See Saikal (2019; pp. 215-224) for a comprehensive discussion of the goals, strength, and weaknesses of the JCPOA agreement.

${ }^{10}$ In the appendix, we briefly survey the political and economic developments that led to the JPOA and JCPOA agreements. We also show how these agreements affected aggregate output, exports, and imports.

${ }^{11}$ The exports value is measured using constant prices in 2010.

${ }^{12}$ Refer to Figures A4 and A5 in the appendix for detailed time series of the quantity and value of Iran's crude oil exports from 1990 to 2017.

13 The exports value is measured using constant prices in 2010.
} 
exceeded $\$ 94$ billion in 2010, the highest level observed in post-war Iran, they declined to about $\$ 42$ billion in 2015; then, they recovered to $\$ 50.61$ in 2017 (World Bank, 2019c). ${ }^{14}$

Despite an increase in exports and imports, trade openness in the manufacturing sector declined after the JCPOA agreement. This decline could be measured using the median of time-varying, industryspecific index of trade openness (i.e., the sum of industry-level exports and imports, divided by output). Between 2012 and 2015, this median varies between 67\% and 73\%. It declines to $41.5 \%$ in 2016, though it increases slightly to $45.8 \%$ in $2017 .{ }^{15}$ The decline in trade openness after the JCPOA agreement is caused by a relatively large recovery in manufacturing output during 2016 and $2017 .{ }^{16}$

\section{Empirical Analyses}

We unpack the effect of the sanctions removal, resulting from the JCPOA agreement, on Iran's non-oil exports by exploring a panel of 28 industries categorized under the manufacturing, mining, and agriculture sectors. The U.N. Comtrade data (U.N., 2020) suggest that about $75 \%$ of the exports for the industries that we study were destined for China, Iraq, U.A.E., India, Afghanistan, and Turkey. ${ }^{17}$ These countries were the essential destination for Iran's non-oil exports before the agreement (in 2013 and 2014), and they remain as crucial after the agreement (in 2016 and 2017). Also, other important non-oil export destinations remain almost the same, though there are some small changes in their relative importance. Table 1 lists the most important destinations for Iran's non-oil exports. ${ }^{18}$ A comparison between the composition of export destinations before and after the agreement suggests that, unlike sustained sanctions (e.g., Haidar, 2017; Esfahani and Rasoulinezhad, 2017), the temporary removal of sanctions as a result of the JCPOA agreement did not lead to any significant export deflections. ${ }^{19}$ Thus,

\footnotetext{
${ }^{14}$ The imports value is measured using constant prices in 2010. Refer to Figure A3 in the appendix for detailed time series of Iran's real aggregate exports and imports from 1990 to 2017.

${ }^{15}$ We compute the above medians using quarterly industry-level exports and imports data for the manufacturing sector in Iran (S.C.I., 2019a). We aggregate the quarterly figures to obtain the annual variations. We, then, compute the measure for industry-specific trade openness using annual industry-level outputs (UNIDO, 2020). Finally, we compute the time-varying medians. Detailed computations are available upon request.

${ }^{16}$ See Figure 3 for quarterly production index of the manufacturing sector in Iran.

${ }^{17}$ This computation is based on annual data for 2013, 2014, 2016, and 2017. As described in Section 4.1, the data for 2015 are not reported in the U.N. Comtrade dataset.

${ }^{18}$ At a given year, at least $90 \%$ of Iran's non-oil exports are sent to the destinations that are listed in Table 1.

${ }^{19} \mathrm{We}$ are grateful to an anonymous referee who reminded us of this important comparison.
} 
rather than focusing on export deflection effects, we examine the impact of sanctions removal on the growth of industry-level exports.

\subsection{Data}

We employ quarterly industry-level export and import information, reported by the Statistical Center of Iran (henceforth, S.C.I.). The dataset in use includes quarterly exports and imports information for 28 industries (at two digits industry classification) from late March 2011 to late March 2018 (S.C.I., 2019a). The S.C.I. reports the quarterly industry-level exports and imports data based on the official calendar in Iran, a solar calendar that begins on March $21 \mathrm{st}^{\mathrm{st}}$. That is why our quarterly data begins and ends in late March. The data are reported in thousand U.S. dollars. For our regression analyses, we employ aggregate measures of quarterly exchange rate (C.B.I., 2019) and producer price index (S.C.I., 2019b) to transform the nominal variations in exports and imports (in thousand U.S. dollars) into real variations in domestic currency: IRI rials.

The dataset in use includes customs information for the agriculture sector, including ISIC 3.1 industries number 1, 2, and 5: Agriculture, Forestry, and Fishing, respectively. It also includes information about the mining sector, including ISIC 3.1 industries number 10, 13, and 14: Coal, Metal Ores, and Other Mining, respectively. Further, it includes information about the manufacturing sector, including ISIC 3.1 industries number 15 to 36 . We, therefore, exclude the mining activities that relate to the extraction of crude oil and natural gas (ISIC 3.1 industry number 11). Still, we include the manufacturing activities that relate to the production of coke and refined petroleum products (ISIC 3.1 industry number 23). Table 2 lists the sectors and industries that are included in our dataset. It also provides detailed information about their median quarterly exports and imports in current U.S. dollars.

Our dataset covers a significant portion of Iran's non-oil exports. Transforming the quarterly information into annual figures, we can compare our data with the official annual aggregate non-oil exports series, published by Central Bank of Iran (C.B.I., 2019). Table 3 shows that the annual aggregate figures that we obtain from our dataset are close to the officially reported time series for non-oil exports. It also shows that, even though oil exports are of great importance in Iran's exporting activities, non-oil 
exports make significant contributions to Iran's current account. Their share, as shown in Figure 1, has recently increased significantly. In particular, within the time window of our study, the median share of non-oil exports in Iran's aggregate exports is about $33 \% .^{20}$

We are also able to compare our data with the U.N. Comtrade data (U.N., 2020). ${ }^{21}$ Unlike the data used in our study, the U.N. Comtrade dataset offers scattered coverage for Iran's merchandise trade. Around the time of the JCPOA agreement, it only reports annual exports and imports data for 2013, 2014, 2016, and 2017, with no coverage for 2015. We can, yet, compare the two datasets for the aforementioned time periods. To do so, we first transform the quarterly information in the S.C.I. dataset into annual figures. We also aggregate the annual figures in the U.N. Comtrade dataset over the entire set of trade partners. We then compare the aggregate annual figures. As shown in Table 4, the S.C.I. exports data is comparable with the U.N. data, available for 2013, 2014, 2016, and 2017. Also, the import data for 2013 and 2017 match the U.N. data well. Despite small differences, therefore, we are confident that the aggregate figures obtained from our dataset are comparable to the total figures obtained from the U.N. Comtrade dataset. ${ }^{22}$

The median quarterly export figures that are reported in Table 2 suggest that the Chemical Products industry, Coke and Refined Petroleum industry, Food and Beverages industry, and Basic Metals industry are of vital importance in Iran's non-oil exports. From 2011 to 2018, the median quarterly nominal exports of Chemical Products from Iran to the rest of the world are about $\$ 2.41$ billion. The median quarterly exports for Coke and Refined Petroleum products are about $\$ 1.78$ billion. The median quarterly exports of Food and Beverages are about $\$ 0.97$ billion. And the median quarterly exports of Basic Metals are about $\$ 0.81$ billion.

\footnotetext{
${ }^{20}$ For a given year, we divide CBI's official oil exports, as given in Table 3, by the sum of CBI's official oil exports and CBI's official non-oil exports. We repeat the same exercise for all years. Then, we take the median. The obtained median is about 33\%. If, instead of CBI's official non-oil exports, one repeats the exercise above using aggregate figures in our dataset, as given in Table 3, the obtained median would be slightly higher than $37 \%$. Both measures show the relative importance of non-oil exports in Iran's aggregate exports.

${ }^{21}$ We are grateful to an anonymous referee who reminded us of this important comparison.

22 Though they are comparable, there are some differences between exports figures in Tables 3 and 4; these differences are caused by differences in calendars.
} 
We measure the contribution of a given industry to Iran's non-oil exports using Equation 1.

Consider industry $i$ at quarter $q$. We compute the share of industry $i$ in exporting activities at quarter $q$ by dividing its real exports $\left(X_{i, q}\right)$, measured in IRI rials, by the total real non-oil exports observed in our dataset, measured in IRI rials:

$$
\operatorname{Share}_{X, i, q}=X_{i, q} / \sum_{j=1}^{N} X_{j, q}
$$

We, then, compute the industry-specific median of Share $_{X, i, q}$. We use the obtained time-invariant median as our industry-specific measure for the contribution of a given industry to non-oil exports. Figure 2 plots the cross-section variations in the measure above (in percentage). The obtained pattern verifies the relative importance of the Chemical Products industry, Coke and Refined Petroleum industry, Food and Beverages industry, and Basic Metals industry in Iran's non-oil exports.

We employ multiple control covariates in our empirical analyses. First, we control for foreign outputs. Given data limitations for industry-specific quarterly outputs, we rely on sector-specific quarterly production in China. As shown in Table 1, China is the essential destination for Iran's non-oil exports between 2013 and 2017, before and after the JCPOA agreement. ${ }^{23}$ Using the data reported by the National Bureau of Statistics of China (2020), we employ an index for the quarterly changes in the real valueadded of the "primary industries" (matching the agriculture sector in our dataset) and the "secondary industries" (matching the manufacturing and mining sectors in our dataset). Second, we control for domestic outputs. Again, given data limitations for industry-specific quarterly outputs, we rely on Iran's sector-specific quarterly output in the manufacturing, mining, and agriculture sectors (S.C.I., 2019c).

We normalize our sector-specific production indexes to 100 for spring 2011, the first quarter in our dataset. Figures 3-5 show the time series of quarterly production indexes for Iran's manufacturing, mining, and agriculture sectors from late March 2011 to late March 2018. ${ }^{24}$ Iran's manufacturing output

\footnotetext{
${ }^{23}$ The data from UN Comtrade (UN, 2020) suggest that on average about $24.37 \%$ of Iran's non-oil exports were destined to China in 2013, 2014, 2016, and 2017.

${ }^{24}$ To save space, we do not include the time series of quarterly production indexes for China. Those time series plots are available upon request.
} 
(Figure 3) declines significantly starting from fall 2011, it remains stagnated until spring 2016, and it ultimately reverts to its initial level by winter 2018. The U-shaped pattern of manufacturing output index closely follows the timing of the severe imposition and the subsequent removal of sanctions against Iran. ${ }^{25}$ Unlike the manufacturing sector, we do not observe a U-shaped pattern in the time series of production in the mining and agriculture sectors; mining production appears to be largely unaffected by sanctions or by their removal (Figure 4), and agricultural production has the expected seasonal pattern (Figure 5).

As for our third covariate, we control for the effective real exchange rate. For this, we use a monthly effective real exchange rate measure reported by Bruegel (2019). ${ }^{26}$ We transform the monthly index to quarterly index by computing the average effective real exchange rates for the months that are included in a given quarter. We, again, normalize this index to 100 for the first quarter in our dataset.

Lastly, we control for industry-specific quarterly imports to capture the import competition effect. Like exports, we observe quarterly variations in industry-specific imports from spring 2011 to winter 2018 (S.C.I., 2019a).

\subsection{Empirical Approach}

The underlying question of this study is the following: did the removal of international sanctions, resulting from the JCPOA agreement, positively contribute to the growth rate of non-oil exports from Iran to the rest of the world? To address this question, we employ a linear dynamic export growth function under a panel set-up (with 28 industries and 28 quarters). Among other studies, this function is used in Santos-Paulino (2002), Santos-Paulino and Thirlwall (2004), and Ratnaike (2012). While these studies examine the effects of trade liberalization, we examine the effect of a political agreement that led to sanctions removal.

\footnotetext{
${ }^{25}$ See the appendix for more details about the timing of sanctions and their removal. In fact, a similar U-shaped pattern could be observed when one examines Iran's PPP GDP (World Bank, 2019b), illustrated by Figure A1 in the appendix.

${ }^{26}$ Bruegel computes the effective real exchange rate measures using a method developed in Darvas (2012). We use the rates that are based on the trade flows between Iran and 143 trading partners.
} 
Considering the theoretical importance of income and price effects (e.g., Goldstein and Khan, 1985), Santos-Paulino (2002) and Santos-Paulino and Thirlwall (2004) introduce a dynamic export growth model using which they examine the effects of trade liberalization on export performance in developing countries. ${ }^{27}$ In their model, export growth responds to changes in relative national prices (measured by real exchange rate), foreign output, and trade policy. To capture the transitional effects of policy changes, they include lagged export growth in their models. Also, following the same approach, Ratnaike (2012) shows that, along with foreign output, domestic output variations may determine the growth rate of exports in such models.

Motivated by the above studies, we model the industry-specific average quarterly growth rate of real exports as a function of its lags (up to 3 quarters) and the growth rates of foreign outputs, domestic outputs, and effective real exchange rate. We also test for the effects of import competition by controlling for the growth rate of imports. Further, we capture the mechanics of diminishing growth rates by controlling for exogenous lagged levels of exports.

The primary variable of interest in our study is the industry-specific average quarterly growth rate of real exports, defined as:

$$
g x_{i, q}=\frac{1}{4} \times\left(\ln \left(X_{i, q}\right)-\ln \left(X_{i, q-4}\right)\right)
$$

where $X_{i, q}$ is industry $i$ 's real exports at quarter $q$, measured in IRI rials. This measure would allow us to compare the real exports at quarter $q$ with the real exports during the same quarter over the previous year, $q-4$. This particular definition of growth rate is of importance for us as some of the industries in our dataset exhibit seasonal patterns.

As opposed to level variations in real exports, the panels of average quarterly growth rates do not contain unit roots. To test for this, we employ a panel unit root test, developed by Breitung (2000). This test is useful for our dataset as the number of cross-section and time units are relatively large. Test results suggest that we cannot reject the null hypothesis that our panels contain unit roots when we examine the

\footnotetext{
${ }^{27}$ A similar model is used by Santos-Paulino (2007), Nenci (2011), Cali and Te Velde (2011).
} 
variations in real log exports ( $\mathrm{p}$-value $=98.63 \%$ ). In contrast, we can safely reject the null hypothesis that our panels contain unit roots when we examine the variations in the average quarterly growth rate of real exports ( $\mathrm{p}$-value $=0 \%) .{ }^{28}$ The panels of $g x_{i, q}$ series are, thus, likely to be stationary.

We control for lagged quarterly growth rates of industry-specific exports along with an exogenous lagged level of industry-specific exports. We also control for quarterly growth rates of sectorspecific foreign and domestic production, aggregate effective real exchange rate, and industry-specific imports - we similarly compute these growth rates as in Equation 2. We include a time trend and a vector of time dummies. We also include a fixed effect parameter to control for time-invariant idiosyncratic characteristics of the industries that are included in our dataset.

We employ a linear dynamic panel data regression model. As expected, the correlation between lagged growth rates of industry-level exporting activities and the industry fixed effect parameter presents an identification problem. To address this problem, we identify and estimate the parameters of interest using the canonical system generalized method of moments approach, developed by Arellano and Bover (1995) and Blundell and Bond (1998). We employ a system in which lagged levels are used as instruments for the first difference equation, and lagged differences are used as instruments for the level equation. Our baseline regression model is as follows:

$$
\begin{gathered}
g x_{i, q}=\sum_{t=1}^{3} \alpha_{x, t} \times g x_{i, q-t}+\alpha_{y *} \times g y_{s, q}^{*}+\alpha_{y} \times g y_{s, q}+\alpha_{e} \times g e_{q}+\alpha_{m} \times g m_{i, q} \\
+\alpha_{X} \times \ln \left(X_{i, q-8}\right)+\alpha_{t} \times q+Q^{\prime} \alpha_{Q}+\eta_{i}+\varepsilon_{i, q}
\end{gathered}
$$

In this regression function, $g x_{i, q}$ is the average quarterly growth rate of industry $i$ 's exports at quarter $q$, as defined in Equation 2. For this growth rate, we compare the contemporaneous real exports with real exports during the comparable quarter over the last year (i.e., quarter $q-4)$. Thus, we limit the autoregressive terms to three lags. $g y_{s, q}^{*}$ and $g y_{s, q}$ are the growth rate of sector-specific foreign and domestic outputs, respectively. $g e_{q}$ is the growth rate of the aggregate effective real exchange rate. And

\footnotetext{
${ }^{28} \mathrm{We}$ are grateful to an anonymous referee who reminded us of this important comparison. Detailed test statistics are available upon request.
} 
$g m_{i, q}$ is the growth rate of industry $i$ 's imports at quarter $q$. Also, since we examine the growth rate of real exports, we control for lagged levels of real exports, $\ln \left(X_{i, q-8}\right)$. Given the way that we define the average quarterly growth rate, the proper exogenous lagged level would belong to the same quarter over two years ago (i.e., quarter $q-8$ ). Further, $q$ is the quarterly time variable, capturing the time trend. $Q$ is a vector of quarterly time dummies, controlling for the effect of time-varying shocks that are common among all industries. $\eta_{i}$ is the industry fixed effect parameter. And $\varepsilon_{i, t}$ is the error term under usual assumptions.

Applying the system generalized method of moment, we employ instrumental variables in order to identify the parameters of interest in Equation 3. Our system of the equation includes a first differenced equation and a level equation. For our first differenced equation, we employ the second and the third lags of growth rates for exports, imports, and domestic output as instruments. We also use foreign output, exchange rate, and exogenous lagged level of exports as a standard instrument. For our level equation, we employ the lagged difference of growth rates for exports, imports, and domestic output as instruments. We again use foreign output, exchange rate, and exogenous lagged level of exports as a standard instrument, along with quarterly time variable, and quarterly time dummies.

We modify the regression function in Equation 3 in two ways to capture the effect of the JCPOA agreement. First, we include a binary variable, called Agreement, that is set equal to 1 for the quarter during which the JCPOA agreement was reached (i.e., summer 2015) and the quarters that follow. It is set equal to zero, otherwise. Alternatively, we make use of an ordinal variable to capture the effects of the implementation of the interim agreement, JPOA, and the comprehensive deal, JCPOA. We normalize our ordinal variable to 1 following the implementation of the JPOA, starting from winter $2014 .{ }^{29} \mathrm{We}$, then, set it equal to 2 following the implementation of the JCPOA, starting from winter $2016 .{ }^{30}$ And we set it equal to zero for the remaining periods, preceding winter 2014. This ordinal measure may, therefore, gauge the

\footnotetext{
29 The JPOA agreement was implemented starting from January $19^{\text {th }}, 2014$ (Reuters, 2014).

30 The JCPOA agreement was implemented starting from January $16^{\text {th }}, 2016$ (UN Security Council, 2015).
} 
degree of political agreements between Iran and the permanent members of the U.N. Security Council, plus Germany.

Second, considering the varying importance of different industries in Iran's non-oil exports, we explore the heterogeneity in export responses by adding an interaction term using our binary variable: Agreement $_{q} \times$ Share $_{X, i, q-8}$. In this interaction term, Share ${ }_{X, i, q-8}$ is the exogenous lagged share of industry $i$ 's exports in Iran's non-oil exports as defined in Equation 1; when we use the interaction term above, we also include a control for Share $_{X, i, q-8}$. We, further, use an alternative interaction term: Agreement $_{q} \times$ Median(Share $\left.{ }_{X, i, q}\right)$. In this interaction term, Median(Share ${ }_{X, i, q}$ ) is a time-invariant variable, measuring the central tendency of the distribution for the time-varying share of industry i's exports in Iran's non-oil exports as plotted in Figure 2; when we use the alternative interaction term, we also include a control for Median $\left(\operatorname{Share}_{X, i, q}\right)$. We explore the heterogeneity in responses using the parameters associated with the interaction terms above. Equation 4 incorporates the said modifications:

$$
\begin{gathered}
g x_{i, q}=\sum_{t=1}^{3} \alpha_{x, t} g x_{i, q-t}+\alpha_{y *} \times g y_{s, q}^{*}+\alpha_{y} \times g y_{s, q}+\alpha_{e} \times g e_{q}+\alpha_{m} \times g m_{i, q} \\
+\beta_{A} \text { Agreement }_{q}+\beta_{I} \text { Agreement }_{q} \times \text { Share }_{i(, q-8)}+\beta_{S} \text { Share }_{i(, q-8)} \\
+\alpha_{t} q+Q^{\prime} \alpha_{Q}+\eta_{i}+\varepsilon_{i, q}
\end{gathered}
$$

where Share $_{i, q-8)}$ is either equal to Share $_{X, i, q-8}$ (an exogenous time-varying measure) or Median(Share Xi, $_{, q}$ ) (an exogenous time-invariant measure). The remaining variables are the same variables that we use in our baseline regression (Equation 3).

Conditional upon the wide range of control covariates, we assume that the timing of the agreement, as measured by Agreement, is exogenous to the variations in the growth rate of Iran's non-oil exports at the disaggregated industry level. Also, Share ${ }_{X, i, q-8,}$ and Median(Share ${ }_{X, i, q}$ ) measure industryspecific characteristics that are exogenous to variations in our dependent variable; the first one is lagged for eight periods, and the second one represents time-invariant characteristics. We, therefore, employ them as standard instruments for the primary difference and level equations. 


\subsection{Results}

We first report the estimation results for the parameters in our baseline regression function, as given by Equation 3. We organize the results in Table 5. We employ 552 observations. Our dataset includes 28 industries over 28 quarters. Thus, there are $784(=28 \times 28)$ observations available to us. However, given the control for lagged levels, $\ln \left(X_{i, q-8}\right)$, we are unable to use the information for the first eight quarters for each industry. That implies that, by construction, we can only employ $560(=28 \times 20)$ observations. Plus, no Tobacco products exports are reported for the winter of 2013. Because of that, we cannot use 8 more observations. That leaves us with 552(=560-8) observations.

The results in column $I$ of Table 5 suggest that the second and the third lags of export growth rates are positively correlated with the contemporaneous growth rate of exports for a given industry. As expected, we also find that the lagged level of exports, $\ln \left(X_{i, q-8}\right)$, is negatively correlated with the contemporaneous growth rate of exports for a given industry: the greater the initial level of exports, the lower the contemporaneous growth rate. These parameters remain significant after we add further control covariates.

In columns $I I$ and $I I I$ in Table 5, we report the results with more control covariates. We find that an increase in the growth rate of foreign real output, as measured by China's sector-specific output, leads to an increase in the growth rate of real exports. In contrast, we find that an increase in the growth rate of domestic real output, as measured by Iran's sector-specific output, leads to a decline in the growth rate of real exports. Similar correlations are reported by Ratnaike (2012), who argues that the negative effect of an increase in domestic output on exports could be the result of resource diversion towards the domestic market and away from export destinations. We also find that growth in an effective real exchange rate has no significant effects on contemporaneous export growth. We find the same for imports.

As mentioned in Section 4.2, we estimate the key parameters of interest using the system generalized method of moment à la Arellano and Bover (1995) and Blundell and Bond (1998). We employ the second and the third lags of growth rates for exports, imports, and domestic output as 
instruments for our first differenced equation. We also employ the lagged difference of growth rates for exports, imports, and domestic output as instruments for our level equation. To test the validity of the moment conditions in our system, we run a test proposed by Arellano and Bond (1991) (henceforth, A.B. Test). In particular, we examine the presence of first-order autocorrelation using A.B. Test for AR(1) and the lack of second- and third-order autocorrelations using A.B. Test for AR(2) and AR(3). The null hypothesis implying no autocorrelation, we report the p-values for the tests in Table 5. The obtained test results suggest that while we have some evidence for the autocorrelation of order 1 , we cannot reject the null hypothesis of no autocorrelation of order 2 and 3. The moment conditions used in our system may, therefore, be valid.

Employing the observations used in our baseline estimations, a comparison between the unconditional distributions of the average quarterly growth rate of real exports before and after the JCPOA agreement shows that the mean growth rate is higher after the agreement when compared to the mean growth rate before the agreement. ${ }^{31}$ We plot the distributions in Figure 6. Before the agreement (i.e., before summer 2015), exports are contracting at an average rate of 3.1\%. After the agreement, however, exports are growing at an average rate of $1.7 \%$. To examine the shift in distribution, we employ the regression function described in Equation 4 to estimate parameter $\beta_{A}$, quantifying the effects of the JCPOA agreement on Iran's non-oil exports.

In Table 6, we organize our estimations results for the parameters of Equation 4. In the absence of any interaction terms (column $I$ ), our estimation for parameter $\beta_{A}$ suggests that, conditional upon a wide range of covariates, industry-specific exports grow significantly faster after the JCPOA agreement. In particular, given the initial level of exports and lagged growth rates, we find that exports in non-oil industries grow, on average $9.9 \%$ faster following the agreement in summer 2015 (robust standard error is equal to $3.9 \%$ ). A similar pattern emerges when we use the ordinal measure for the JPOA and JCPOA agreements. In this case, employing the same vector of control covariates (column $I I$ ), our estimation for

\footnotetext{
${ }^{31}$ We observe a similar difference between the median growth rates before and after the agreement. See Figure 6.
} 
parameter $\beta_{A}$ suggests that industry-specific exports grow significantly faster as Iran and the permanent members of the U.N. Security Council, plus Germany, reached the interim and, then, the comprehensive agreements. In both cases (columns $I$ and $I I$ ), we find that $\beta_{A}$ is statistically greater than zero and economically significant, suggesting that sanctions removal contributed positively to the growth rate of non-oil exports in Iran.

We are also interested in identifying the industries that benefit the most from the JCPOA agreement. For this, we employ the interaction terms that were introduced in Equation 4, and we estimate parameters $\beta_{A}, \beta_{I}$, and $\beta_{S}$. We report the estimation results in columns $I I I$ and $I V$ of Table 6 . The parameter associated with our binary measure for the JCPOA agreement $\left(\beta_{A}\right)$ remains significantly greater than zero and of similar magnitude, while the parameter associated with the interaction term $\left(\beta_{I}\right)$ turns out to be significantly less than zero. In column $I I I$, we include the lagged share in exporting activities: Share $_{X, i, q-8 .}$ We interact this measure with the JCPOA indicator variable, and we control for it separately. In column $I V$, we include the time-invariant measure for the importance of a given industry in non-oil exporting activities: Median(Share ${ }_{X, i, q}$ ). Again, we interact this measure with the JCPOA indicator variable, and we control for it separately. In both cases, we find that the interaction parameter, $\beta_{I}$, is statistically less than zero. Conditional upon a wide range of covariates, our findings suggest that the exports of industries with relatively low shares in Iran's non-oil exports grow significantly faster following the sanctions removal, resulting from the JCPOA agreement. Also, in both cases, we find that parameter $\beta_{S}$ is significantly greater than zero; this implies that on average the exports of industries with relatively low shares in Iran's non-oil exports grow slowly when compared with industries with relatively high shares.

The estimated parameters for the control covariates in Table 6 are quite similar to the estimated parameters in Table 5. The only exception is the estimated parameter for the real exchange rate, which becomes significant under the regression with ordinal agreement measure (column $I I$ ). Nevertheless, this parameter remains insignificant in all other cases. 
As before, we find that the second and the third lags of export growth rates are positively correlated with the contemporaneous growth rate of exports for a given industry. We also find that the lagged level of exports is negatively correlated with the contemporaneous growth rate of exports. Further, as in Ratnaike (2012), we find that while growth in foreign output is positively correlated with growth in exports, domestic output growth leads to a decline in export growth. Lastly, we find that effective real exchange rate and imports have no significant effects on export growth; excluding those covariates from our regressions has no significant effects on the estimated parameters for the agreement variable, its interaction with exports share, or remaining control covariates. ${ }^{32}$

The AB Test results for the regressions in Table 6 are quite similar to the test results for the regression that we report in column III of Table 5. In particular, the obtained p-values suggest that, while we have some evidence for the autocorrelation of order 1, we cannot reject the null hypothesis of no autocorrelation of orders 2 and 3. The moment conditions may, therefore, be valid.

In line with the estimation results reported in columns $I I I$ and $I V$ of Table 6 , there is some descriptive evidence for the significant effects of the JCPOA agreement on the exports of industries that have relatively small shares in Iran's non-oil exports. Employing the observations used in our estimations, we make a comparison between the unconditional average growth rates of industry-specific exports before and after the JCPOA agreement. Sorted by the changes, Table 7 shows that the majority of industries that benefit from the agreement have relatively low shares in non-oil exports. Their exports were, in fact, severely affected by sanctions. Once sanctions were removed, their exports grow relatively faster, making up for prior contractions. A similar pattern emerges if, instead of averages, we compare the unconditional median growth rates of industry-specific exports before and after the agreement. See Table 8 for more detail.

Taken together, the estimation results in Table 6, along with the patterns that emerge in Tables 7 and 8 suggest that the growth rate of Iran's non-oil exports is significantly higher after the JCPOA

\footnotetext{
${ }^{32}$ Detailed estimation results are available upon request.
} 
agreement when compared to a similar window of time before the deal. It is, in particular, evident that the exports of industries that have relatively low shares in Iran's non-oil exporting activities grow significantly faster than industries with relatively high shares in non-oil exports.

The above pattern is, indeed, expected when one considers the non-oil export deflection effect of Iran sanctions (Haidar, 2017). Unlike oil exports, Table 3 shows that non-oil exports do not fluctuate greatly from 2011 to 2018; that is why the share of non-oil exports increased significantly during this time period (Figure 1). The greater stability of non-oil exports is, in part, the result of significant export deflection to non-sanctioning destinations. In particular, as Haidar (2017) suggests, large non-oil exporters who produce core and homogeneous products are more likely to deflect their exports from sanctioning to non-sanctioning destinations. They are likely to suffer less from sanctions when compared to small exporters. A short-lived political agreement is, therefore, expected to be of less importance for them. That may explain why we observe a significant effect from the JCPOA agreement on the export of industries that have relatively low shares in Iran's non-oil exports.

Plus, our findings are in line with recent studies that examine the effect of trade liberalization on export diversification. Aditya and Acharyya (2015) offer a set of theoretical propositions, suggesting that tariff reductions may lead to export diversification across and within sectors. Also, Osakwe, SantosPaulino, and Dogan (2018), Gnangnon (2019), and Giri et al. (2019) provide some empirical evidence for this channel. The latter study, in particular, suggests that reducing trade barriers may significantly contribute to export diversification among commodity-exporting countries, like Iran. Unlike the above studies that examine trade liberalization, our paper explores the short-run effect of a political agreement. Nevertheless, the significant effects of this short-lived agreement on the exports of industries that have a relatively small share in Iran's non-oil exports are indicative of the importance of reducing trade barriers for export diversification.

\section{Conclusion}

We explored the effects of sanctions removal, resulting from the JCPOA agreement on Iran's non-oil exports. Our findings suggest that, despite its short life, the JCPOA agreement significantly contributed to 
the growth rate of non-oil exports. In particular, industries that have relatively low shares in Iran's non-oil exports benefited from this agreement: their exports grew much faster than the leading industries.

There are four caveats when interpreting the findings above. Three of them stem from limited data availability, and the last one relates to the nature of this study. First, the data in use come from industry-level observations, masking firm-level distributions across different industries. Second, the data in use aggregate industry-level exports across various destinations, hiding important bilateral characteristics. Third, even though we control for sector-specific domestic and foreign production indexes, we do not have access to industry-level variations in output. It would have been ideal to have access to disaggregated quarterly observations across firms, industries, and destinations, including information about trade and output. The existing datasets, however, offer less detailed information at a quarterly frequency. As for the fourth caveat, we are only able to estimate the short-run effect of this particular agreement. As previously mentioned, the JCPOA agreement was finalized in summer 2015. However, the U.S. terminated its participation in spring 2018 and re-imposed sanctions as of summer 2018. As a result, we have a limited window of time, and we are unable to explore the long-run effects in such a limited window.

Notwithstanding these caveats, we are able to employ quarterly industry-level data to examine the short-run effect of the JCPOA agreement. Our findings suggest that even temporary sanctions relief, resulting from a short-lived political agreement, could positively contribute to export growth; in particular, sanctions relief may impact industries that have relatively low shares in exporting activities and improve export diversification. Using more detailed data, future research may unmask the channels by which such agreements affect the growth of non-oil exports in Iran. 


\section{Tables}

Table 1: Major non-oil export destinations for Iran

\begin{tabular}{|c|c|c|c|c|c|c|c|c|}
\hline & \multicolumn{4}{|c|}{ Before the JCPOA Agreement } & \multicolumn{4}{|c|}{ After the JCPOA Agreement } \\
\hline & \multicolumn{2}{|c|}{2013} & \multicolumn{2}{|c|}{2014} & \multicolumn{2}{|c|}{2016} & \multicolumn{2}{|c|}{2017} \\
\hline 1 & China & $(23.9 \%)$ & China & $(26.1 \%)$ & China & $(23.2 \%)$ & China & $(24.3 \%)$ \\
\hline 2 & Iraq & $(19.4 \%)$ & Iraq & $(17.9 \%)$ & Iraq & $(18.1 \%)$ & Iraq & $(17.4 \%)$ \\
\hline 3 & UAE & $(11.5 \%)$ & UAE & $(11.2 \%)$ & UAE & $(15.6 \%)$ & UAE & $(12.1 \%)$ \\
\hline 4 & India & $(7.9 \%)$ & India & $(7.0 \%)$ & Afghanistan & $(7.3 \%)$ & Afghanistan & $(7.7 \%)$ \\
\hline 5 & Afghanistan & $(7.8 \%)$ & Afghanis & $(6.9 \%)$ & India & $(6.4 \%)$ & India & $(7.0 \%)$ \\
\hline 6 & Turkey & $(5.3 \%)$ & Turkey & $(5.4 \%)$ & Turkey & $(4.0 \%)$ & Turkey & $(4.5 \%)$ \\
\hline 7 & Turkmenistan & $(2.7 \%)$ & Turkmenistan & $(2.8 \%)$ & Pakistan & $(2.3 \%)$ & Pakistan & $(2.5 \%)$ \\
\hline 8 & Pakistan & $(2.1 \%)$ & Pakistan & $(2.7 \%)$ & Turkmenistan & $(1.6 \%)$ & Thailand & $(2.0 \%)$ \\
\hline 9 & Egypt & $(2.0 \%)$ & Italy & $(1.7 \%)$ & Oman & $(1.6 \%)$ & Indonesia & $(1.8 \%)$ \\
\hline 10 & Azerba & $(1.5 \%)$ & Hong K & $(1.5 \%)$ & Italy & $(1.4 \%)$ & Oman & $(1.4 \%)$ \\
\hline 11 & South Korea & $(1.1 \%)$ & Egypt & $(1.5 \%)$ & Vietnam & $(1.2 \%)$ & South Korea & $(1.2 \%)$ \\
\hline 12 & Russia & $(1.0 \%)$ & Azerbaijan & $(1.2 \%)$ & Thailand & $(1.1 \%)$ & Italy & $(1.2 \%)$ \\
\hline 13 & Hong K & $(1.0 \%)$ & South Korea & $(1.2 \%)$ & South Korea & $(1.0 \%)$ & Turkmenistan & $(1.1 \%)$ \\
\hline 14 & Unspecified & $(0.9 \%)$ & Vietnam & $(1.0 \%)$ & Hong Kong & $(1.0 \%)$ & Hong Kong & $(1.0 \%)$ \\
\hline 15 & Germany & $(0.8 \%)$ & Oman & $(0.8 \%)$ & Singapore & $(0.9 \%)$ & Vietnam & $(1.0 \%)$ \\
\hline 16 & Tajikistan & $(0.8 \%)$ & Germany & $(0.8 \%)$ & Germany & $(0.8 \%)$ & Syria & $(0.9 \%)$ \\
\hline 17 & Vietnam & $(0.7 \%)$ & Russia & $(0.8 \%)$ & Azerbaijan & $(0.8 \%)$ & Germany & $(0.8 \%)$ \\
\hline 18 & Kazakhstan & $(0.7 \%)$ & Tajikistan & $(0.6 \%)$ & Syria & $(0.8 \%)$ & Russia & $(0.8 \%)$ \\
\hline 19 & Italy & $(0.6 \%)$ & Kazakhstan & $(0.6 \%)$ & Spain & $(0.7 \%)$ & Azerbaijan & $(0.8 \%)$ \\
\hline 20 & Oman & $(0.5 \%)$ & Kuwait & $(0.5 \%)$ & Russia & $(0.6 \%)$ & Egypt & $(0.7 \%)$ \\
\hline
\end{tabular}

Note: For a given year, the share of a given export destination in aggregate non-oil exports are reported in parentheses. 
Table 2: Sectors and industries that are included in our dataset

\begin{tabular}{|c|c|c|c|c|}
\hline Sector & Industry & $\begin{array}{l}\text { ISIC } \\
\text { Code }\end{array}$ & $\begin{array}{c}\text { Median } \\
\text { Quarterly Exports }\end{array}$ & $\begin{array}{c}\text { Median } \\
\text { Quarterly Imports }\end{array}$ \\
\hline & & & \multicolumn{2}{|c|}{ million dollars (nominal values) } \\
\hline \multirow{3}{*}{ Agriculture } & Agriculture & 1 & 437.03 & 1426.53 \\
\hline & Forestry & 2 & 4.31 & 3.86 \\
\hline & Fishing & 5 & 40.57 & 1.93 \\
\hline \multirow{3}{*}{ Mining } & Coal & 10 & 2.18 & 43.31 \\
\hline & Metal Ores & 13 & 260.38 & 25.48 \\
\hline & Other Mining & 14 & 68.02 & 20.70 \\
\hline \multirow{22}{*}{ Manufacturing } & Food \& Bev. & 15 & 970.48 & 1356.53 \\
\hline & Tobacco & 16 & 0.63 & 61.71 \\
\hline & Textile & 17 & 257.88 & 201.80 \\
\hline & Wearing App. & 18 & 52.10 & 22.96 \\
\hline & Leather & 19 & 48.41 & 4.70 \\
\hline & Wood & 20 & 7.46 & 221.80 \\
\hline & Paper & 21 & 8.07 & 291.99 \\
\hline & Publishing & 22 & 2.79 & 4.85 \\
\hline & Coke \& Petrol. & 23 & 1778.85 & 50.89 \\
\hline & Chemicals & 24 & 2409.55 & 1764.28 \\
\hline & Rub. \& Plastic & 25 & 237.90 & 268.15 \\
\hline & Other Non-metal. & 26 & 415.14 & 153.61 \\
\hline & Basic Metals & 27 & 814.29 & 972.88 \\
\hline & Fab. Met. Prod. & 28 & 115.67 & 199.04 \\
\hline & Mach. \& Equ. N.E.C. & 29 & 144.38 & 1980.49 \\
\hline & Elect. \& Comp. Equ. & 30 & 0.12 & 217.98 \\
\hline & Elec. Mach. \& App. N.E.C. & 31 & 60.55 & 353.48 \\
\hline & Radio \& TV & 32 & 2.96 & 543.87 \\
\hline & Med., Prec., \& Opt. & 33 & 6.05 & 363.80 \\
\hline & Motor Vehicles & 34 & 49.41 & 1120.02 \\
\hline & Other Trans. Equ. & 35 & 22.55 & 165.83 \\
\hline & Furn. \& Manu. N.E.C. & 36 & 19.44 & 59.83 \\
\hline
\end{tabular}


Table 3: A comparison between aggregate annual figures in our dataset with the C.B.I.'s official annual non-oil exports time series

\begin{tabular}{|c|c|c|c|c|}
\hline Year & Year & $\begin{array}{c}\text { C.B.I.'s Official Oil } \\
\text { Exports Time Series }\end{array}$ & $\begin{array}{c}\text { C.B.I.'s Official Non- } \\
\text { oil Exports Time Series }\end{array}$ & $\begin{array}{c}\text { Aggregate Figures in } \\
\text { Our Dataset }\end{array}$ \\
\hline Greg. Cal. & IRI Cal. & \multicolumn{3}{|c|}{ billion dollars (nominal values) } \\
\hline $2011 / 2012$ & 1390 & 119.1 & 26.7 & 26.6 \\
\hline $2012 / 2013$ & 1391 & 68.1 & 29.2 & 32.4 \\
\hline $2013 / 2014$ & 1392 & 64.5 & 28.4 & 31.3 \\
\hline $2014 / 2015$ & 1393 & 55.4 & 33.6 & 36.4 \\
\hline $2015 / 2016$ & 1394 & 31.8 & 31.1 & 35.6 \\
\hline $2016 / 2017$ & 1395 & 55.8 & 28.2 & 39.4 \\
\hline $2017 / 2018$ & 1396 & 65.8 & 32.3 & 39.5 \\
\hline
\end{tabular}

Note: Differences in the non-oil exports values reported in C.B.I.'s data (2019) and the aggregate annual figures in our dataset may be the result of minor differences industry categorization. Though they are comparable, there are some differences between exports figures in Tables 3 and 4; these differences are caused by differences in calendars.

Table 4: A comparison between aggregate annual figures in our dataset with the U.N. Comtrade data

\begin{tabular}{|c|c|c|c|c|}
\hline & \multicolumn{3}{|c|}{ Aggregate Exports Figures } & \multicolumn{2}{c|}{ Aggregate Imports Figures } \\
\hline Year & U.N. Comtrade & Our Dataset & U.N. Comtrade & Our Dataset \\
\hline Greg. Cal. & \multicolumn{4}{|c|}{ billion dollars (nominal values) } \\
\hline 2013 & 31.1 & 31.4 & 46.2 & 46.7 \\
\hline 2014 & 36.0 & 34.6 & 49.6 & 54.7 \\
\hline 2016 & 33.7 & 36.7 & 40.2 & 42.0 \\
\hline 2017 & 36.1 & 36.0 & 46.8 & 57.1 \\
\hline
\end{tabular}

Note: The U.N. Comtrade Database (U.N., 2020) does not report any figures for 2012 and 2015. Also, since our data begins as of March 2011, we cannot draw any comparisons for 2011. Though they are comparable, there are some differences between exports figures in Tables 3 and 4; these differences are caused by differences in calendars. 
Table 5: Baseline results

\begin{tabular}{|lccc|}
\hline & \multicolumn{3}{c}{ II } \\
\hline & \multicolumn{3}{c|}{ Real Export Growth } \\
\hline First Lag of Real Export Growth & 0.020 & 0.023 & -0.028 \\
& $(0.052)$ & $(0.058)$ & $(0.051)$ \\
Second Lag of Real Export Growth & $0.270^{* * *}$ & $0.279^{* * *}$ & $0.227^{* * *}$ \\
& $(0.070)$ & $(0.071)$ & $(0.068)$ \\
Third Lag of Real Export Growth & $0.285^{* * *}$ & $0.286^{* * *}$ & $0.253^{* * *}$ \\
& $(0.088)$ & $(0.072)$ & $(0.077)$ \\
Foreign Real Output Growth & & $1.087^{*}$ & $1.074^{*}$ \\
& & $(0.648)$ & $(0.589)$ \\
Domestic Real Output Growth & & $-1.829^{* *}$ & $-2.267^{* * *}$ \\
& & $(0.768)$ & $(0.808)$ \\
Real Exchange Rate Growth & & -0.015 & 0.020 \\
& & $(0.051)$ & $(0.050)$ \\
Real Import Growth & & & 0.013 \\
& & & $(0.070)$ \\
Exogenous Lagged Level of Real Exports & $-0.004^{* *}$ & $-0.004^{*}$ & $-0.004^{*}$ \\
& $(0.002)$ & $(0.002)$ & $(0.002)$ \\
\hline Number of Observations & 552 & 552 & 552 \\
Fixed Effect & Included & Included & Included \\
Time Trend & Included & Included & Included \\
Time Dummies & Included & Included & Included \\
Arellano and Bond Test, AR(1) & 0.002 & 0.003 & 0.003 \\
Arellano and Bond Test, AR(2) & 0.274 & 0.345 & 0.303 \\
Arellano and Bond Test, AR(3) & 0.229 & 0.189 & 0.135 \\
\hline
\end{tabular}

Notes: For real exports and imports, we use the average quarterly growth rates of exports of industry $i$ at quarter q, as defined in Equation 2. For real foreign and domestic output, we use the average quarterly growth rate of sectorspecific foreign and domestic output indexes, respectively. We report the pvalues for the Arellano and Bond tests (1991), where the null hypothesis implies no autocorrelations. Robust standard errors are reported in parentheses. $* * * p$-value $<0.01, * * p$-value $<0.05, * p$-value $<0.1$. 
Table 6: The JCPOA agreement and average quarterly growth rate of real exports

\begin{tabular}{|c|c|c|c|c|}
\hline & $I$ & II & III & $I V$ \\
\hline & \multicolumn{4}{|c|}{ Real Export Growth } \\
\hline Agreement & $\begin{array}{c}0.099 * * \\
(0.039)\end{array}$ & & $\begin{array}{c}0.110 * * * \\
(0.042)\end{array}$ & $\begin{array}{c}0.112 * * * \\
(0.041)\end{array}$ \\
\hline Ordinal Agreement Variable & & $\begin{array}{c}0.050 * * \\
(0.020)\end{array}$ & & \\
\hline Agreement $\times$ Lagged Share in Exports & & & $\begin{array}{c}-0.242 * \\
(0.132)\end{array}$ & \\
\hline Lagged Share in Exports & & & $\begin{array}{c}0.280 * * \\
(0.116)\end{array}$ & \\
\hline Agreement $\times$ Median Share in Exports & & & & $\begin{array}{c}-0.278 * * \\
(0.134)\end{array}$ \\
\hline Median Share in Exports & & & & $\begin{array}{c}0.359 * * * \\
(0.139)\end{array}$ \\
\hline First Lag of Real Export Growth & $\begin{array}{l}-0.026 \\
(0.051)\end{array}$ & $\begin{array}{l}-0.025 \\
(0.050)\end{array}$ & $\begin{array}{l}-0.027 \\
(0.052)\end{array}$ & $\begin{array}{l}-0.028 \\
(0.052)\end{array}$ \\
\hline Second Lag of Real Export Growth & $\begin{array}{c}0.228 * * * \\
(0.067)\end{array}$ & $\begin{array}{c}0.229 * * * \\
(0.067)\end{array}$ & $\begin{array}{c}0.228 * * * \\
(0.067)\end{array}$ & $\begin{array}{c}0.227^{* * *} * \\
(0.066)\end{array}$ \\
\hline Third Lag of Real Export Growth & $\begin{array}{c}0.250 * * * \\
(0.075)\end{array}$ & $\begin{array}{c}0.254 * * * \\
(0.076)\end{array}$ & $\begin{array}{c}0.252^{* * *} \\
(0.075)\end{array}$ & $\begin{array}{c}0.253 * * * \\
(0.075)\end{array}$ \\
\hline Foreign Real Output Growth & $\begin{array}{l}1.151^{*} \\
(0.601)\end{array}$ & $\begin{array}{l}1.070^{*} \\
(0.592)\end{array}$ & $\begin{array}{l}1.148^{*} \\
(0.589)\end{array}$ & $\begin{array}{l}1.147^{*} \\
(0.590)\end{array}$ \\
\hline Domestic Real Output Growth & $\begin{array}{c}-2.259^{* * *} \\
(0.802)\end{array}$ & $\begin{array}{c}-2.130 * * * \\
(0.814)\end{array}$ & $\begin{array}{c}-2.218^{* * * *} \\
(0.819)\end{array}$ & $\begin{array}{c}-2.219 * * * \\
(0.821)\end{array}$ \\
\hline Real Exchange Rate Growth & $\begin{array}{c}0.021 \\
(0.049)\end{array}$ & $\begin{array}{c}0.210 * * * \\
(0.056)\end{array}$ & $\begin{array}{c}0.020 \\
(0.048)\end{array}$ & $\begin{array}{c}0.020 \\
(0.048)\end{array}$ \\
\hline Real Import Growth & $\begin{array}{c}0.011 \\
(0.070)\end{array}$ & $\begin{array}{c}0.011 \\
(0.070)\end{array}$ & $\begin{array}{c}0.011 \\
(0.071)\end{array}$ & $\begin{array}{c}0.011 \\
(0.072)\end{array}$ \\
\hline Exogenous Lagged Level of Real Exports & $\begin{array}{l}-0.004 * \\
(0.002)\end{array}$ & $\begin{array}{l}-0.004 * \\
(0.002)\end{array}$ & $\begin{array}{c}-0.007 * * \\
(0.003)\end{array}$ & $\begin{array}{c}-0.008 * * * \\
(0.003)\end{array}$ \\
\hline Number of Observations & 552 & 552 & 552 & 552 \\
\hline Fixed Effect & Included & Included & Included & Included \\
\hline Time Trend & Included & Included & Included & Included \\
\hline Time Dummies & Included & Included & Included & Included \\
\hline Arellano and Bond Test, AR(1) & 0.003 & 0.003 & 0.003 & 0.003 \\
\hline Arellano and Bond Test, AR(2) & 0.314 & 0.307 & 0.328 & 0.306 \\
\hline Arellano and Bond Test, AR(3) & 0.117 & 0.131 & 0.121 & 0.120 \\
\hline
\end{tabular}

Notes: The binary variable called Agreement is set equal to 1 starting from the second quarter of 2015, the date by which the JCPOA agreement was reached; it is set equal to zero, otherwise. Ordinal Agreement Variable is set equal to 1 following the implementation of the interim agreement (JPOA), starting from winter 2014, and it is set equal to 2 following the implementation of the comprehensive agreement (JCPOA), starting from winter 2016; it is set equal to zero, otherwise. Share in Exports is defined by Equation 1. Median Share in Exports is the industry-specific median of time-varying Share in Exports; it is, thus, a time-invariant measure. For more, see the notes in Table 5. 
Table 7: A comparison between the average export growth rates before and after the JCPOA agreement

\begin{tabular}{|c|c|c|c|}
\hline Industry & \begin{tabular}{|l|} 
Average Export Growth \\
Rates Before the JCPOA \\
Agreement
\end{tabular} & $\begin{array}{l}\text { Average Export Growth } \\
\text { Rates After the JCPOA } \\
\text { Agreement }\end{array}$ & $\begin{array}{l}\text { Changes in } \\
\text { Average Export } \\
\text { growth Rates }\end{array}$ \\
\hline Elect. \& Comp. Equ. & $-24.03 \%$ & $16.43 \%$ & $40.46 \%$ \\
\hline Furn. \& Manu. N.E.C. & $-18.04 \%$ & $8.25 \%$ & $26.29 \%$ \\
\hline Coal & $-13.66 \%$ & $10.45 \%$ & $24.10 \%$ \\
\hline Other Trans. Equ. & $-24.73 \%$ & $-6.80 \%$ & $17.93 \%$ \\
\hline Other Mining & $-2.00 \%$ & $11.76 \%$ & $13.76 \%$ \\
\hline Leather & $-6.81 \%$ & $-0.53 \%$ & $6.28 \%$ \\
\hline Metal Ores & $-3.24 \%$ & $2.24 \%$ & $5.48 \%$ \\
\hline Paper & $3.90 \%$ & $8.94 \%$ & $5.04 \%$ \\
\hline Med., Prec., \& Opt. & $7.47 \%$ & $12.38 \%$ & $4.91 \%$ \\
\hline Textile & $-2.88 \%$ & $1.56 \%$ & $4.44 \%$ \\
\hline Mach. \& Equ. N.E.C. & $-3.66 \%$ & $0.27 \%$ & $3.93 \%$ \\
\hline Publishing & $-8.46 \%$ & $-4.84 \%$ & $3.62 \%$ \\
\hline Elec. Mach. \& App. N.E.C. & $-1.39 \%$ & $0.00 \%$ & $1.39 \%$ \\
\hline Wood & $3.10 \%$ & $4.45 \%$ & $1.35 \%$ \\
\hline Basic Metals & $1.91 \%$ & $3.16 \%$ & $1.24 \%$ \\
\hline Fab. Met. Prod. & $-3.33 \%$ & $-2.11 \%$ & $1.22 \%$ \\
\hline Rub. \& Plastic & $1.00 \%$ & $2.04 \%$ & $1.04 \%$ \\
\hline Fishing & $-0.96 \%$ & $-0.29 \%$ & $0.67 \%$ \\
\hline Tobacco & $1.80 \%$ & $1.87 \%$ & $0.07 \%$ \\
\hline Motor Vehicles & $-6.17 \%$ & $-6.61 \%$ & $-0.44 \%$ \\
\hline Other Non-metal. & $-1.48 \%$ & $-2.07 \%$ & $-0.59 \%$ \\
\hline Agriculture & $-1.55 \%$ & $-2.48 \%$ & $-0.93 \%$ \\
\hline Chemicals & $0.65 \%$ & $-0.57 \%$ & $-1.22 \%$ \\
\hline Food \& Bev. & $0.85 \%$ & $-0.43 \%$ & $-1.28 \%$ \\
\hline Wearing App. & $3.03 \%$ & $1.23 \%$ & $-1.79 \%$ \\
\hline Coke \& Petrol. & $3.22 \%$ & $0.27 \%$ & $-2.96 \%$ \\
\hline Forestry & $2.86 \%$ & $-3.68 \%$ & $-6.54 \%$ \\
\hline Radio \& TV & $10.28 \%$ & $-6.23 \%$ & $-16.51 \%$ \\
\hline
\end{tabular}

Notes: The computation in this table rely on the observations that are used in our estimations, reported in Tables 5 and 64. Given the lag structure in those estimations (e.g., Equation 4), the periods before the agreement include the quarters from spring 2013 to spring 2015, and the periods after the agreement include the quarters from summer 2015 to winter 2018. Export growth rates are defined by Equation 2. The highlighted industries have relatively large shares in Iran's non-oil exports, as depicted in Figure 2. 
Table 8: A comparison between the median export growth rates before and after the JCPOA agreement

\begin{tabular}{|l|c|c|c|}
\hline Industry & $\begin{array}{l}\text { Median Export Growth } \\
\text { Rates Before the JCPOA } \\
\text { Agreement }\end{array}$ & $\begin{array}{l}\text { Median Export Growth } \\
\text { Rates After the JCPOA } \\
\text { Agreement }\end{array}$ & $\begin{array}{l}\text { Changes in } \\
\text { Median Export } \\
\text { growth Rates }\end{array}$ \\
\hline Elect. \& Comp. Equ. & $-30.46 \%$ & $18.24 \%$ & $48.71 \%$ \\
\hline Other Trans. Equ. & $-22.86 \%$ & $6.05 \%$ & $28.91 \%$ \\
\hline Coal & $-16.51 \%$ & $11.58 \%$ & $28.09 \%$ \\
\hline Furn. \& Manu. N.E.C. & $-18.81 \%$ & $5.89 \%$ & $24.70 \%$ \\
\hline Other Mining & $-1.54 \%$ & $13.03 \%$ & $14.57 \%$ \\
\hline Metal Ores & $-5.78 \%$ & $4.99 \%$ & $10.77 \%$ \\
\hline Elec. Mach. \& App. N.E.C. & $-3.93 \%$ & $3.28 \%$ & $7.21 \%$ \\
\hline Mach. \& Equ. N.E.C. & $-4.60 \%$ & $0.86 \%$ & $5.46 \%$ \\
\hline Leather & $-3.88 \%$ & $0.62 \%$ & $4.50 \%$ \\
\hline Other Non-metal. & $-4.63 \%$ & $-0.61 \%$ & $4.02 \%$ \\
\hline Rub. \& Plastic & $-0.52 \%$ & $3.45 \%$ & $3.97 \%$ \\
\hline Tobacco & $1.80 \%$ & $5.54 \%$ & $3.74 \%$ \\
\hline Fab. Met. Prod. & $-7.35 \%$ & $-3.85 \%$ & $3.50 \%$ \\
\hline Paper & $5.26 \%$ & $8.37 \%$ & $3.11 \%$ \\
\hline Fishing & $-0.08 \%$ & $2.79 \%$ & $2.88 \%$ \\
\hline Publishing & $-8.09 \%$ & $-5.46 \%$ & $2.64 \%$ \\
\hline Textile & $-1.52 \%$ & $0.25 \%$ & $1.77 \%$ \\
\hline Basic Metals & $2.60 \%$ & $2.75 \%$ & $0.15 \%$ \\
\hline Wearing App. & $1.42 \%$ & $1.51 \%$ & $0.09 \%$ \\
\hline Wood & $2.69 \%$ & $1.59 \%$ & $-1.10 \%$ \\
\hline Motor Vehicles & $-8.94 \%$ & $-10.05 \%$ & $-1.11 \%$ \\
\hline Food \& Bev. & $0.98 \%$ & $-0.57 \%$ & $-1.56 \%$ \\
\hline Chemicals & $1.03 \%$ & $-1.03 \%$ & $-2.07 \%$ \\
\hline Med., Prec., \& Opt. & $14.21 \%$ & $10.33 \%$ & $-3.88 \%$ \\
\hline Agriculture & $3.63 \%$ & $-2.56 \%$ & $-6.64 \%$ \\
\hline Forestry & $3.58 \%$ & $-3.07 \%$ & $-8.38 \%$ \\
\hline Coke \& Petrol. & $4.58 \%$ & $-3.80 \%$ & $-25.43 \%$ \\
\hline Radio \& TV & $18.31 \%$ & $-7.12 \%$ & \\
\hline Dor See the & & \\
\hline
\end{tabular}

Note: See the notes in Table 7. 


\section{Figures}

Figure 1: The share of non-oil exports in Iran's aggregate exports

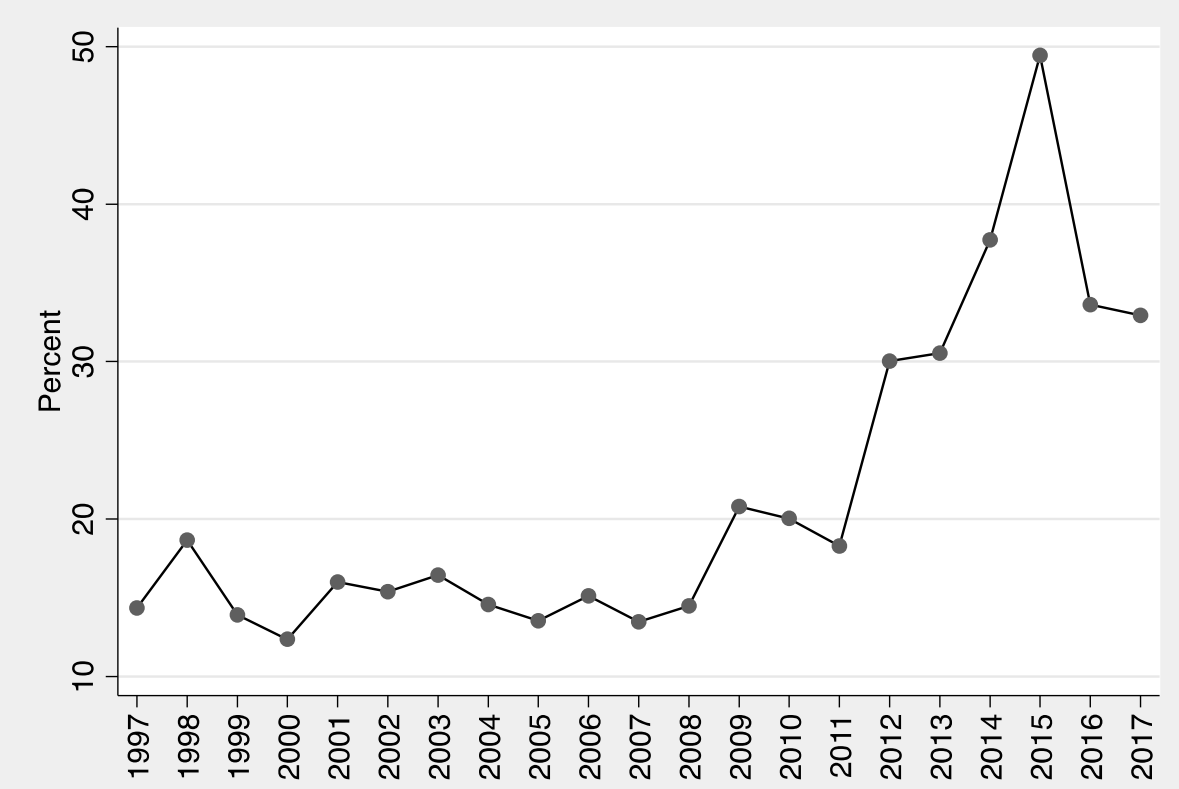

Source: Central Bank of Iran (2019) and authors' computation.

Figure 2: Industry-specific contribution to non-oil exports

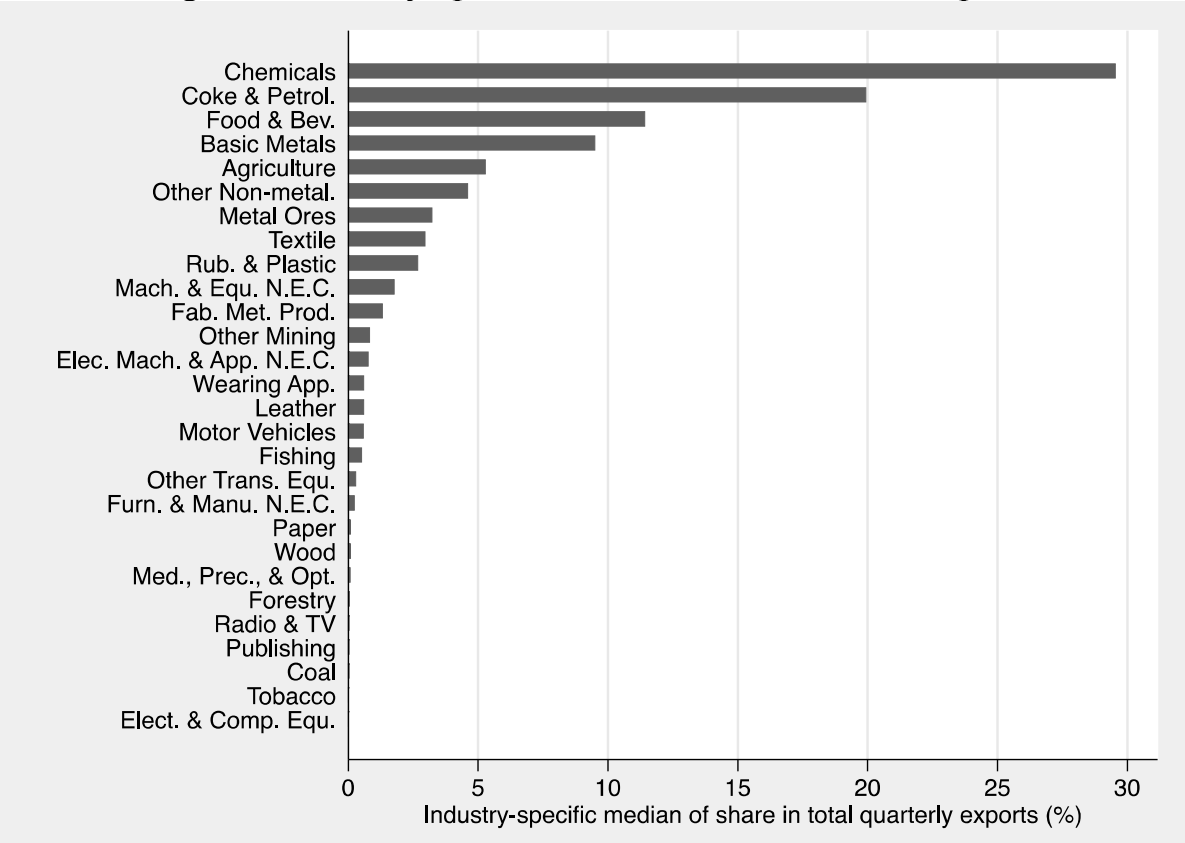

Note: Non-oil exports include the manufacturing activities that relate to the production of coke and refined petroleum (ISIC 3.1 industry number 23). However, they exclude the mining activities that relate to the extraction of crude petroleum and natural gas.

Source: Statistical Center of Iran (2019a) and authors' computation. 
Figure 3: Sector-specific production index for manufacturing sector

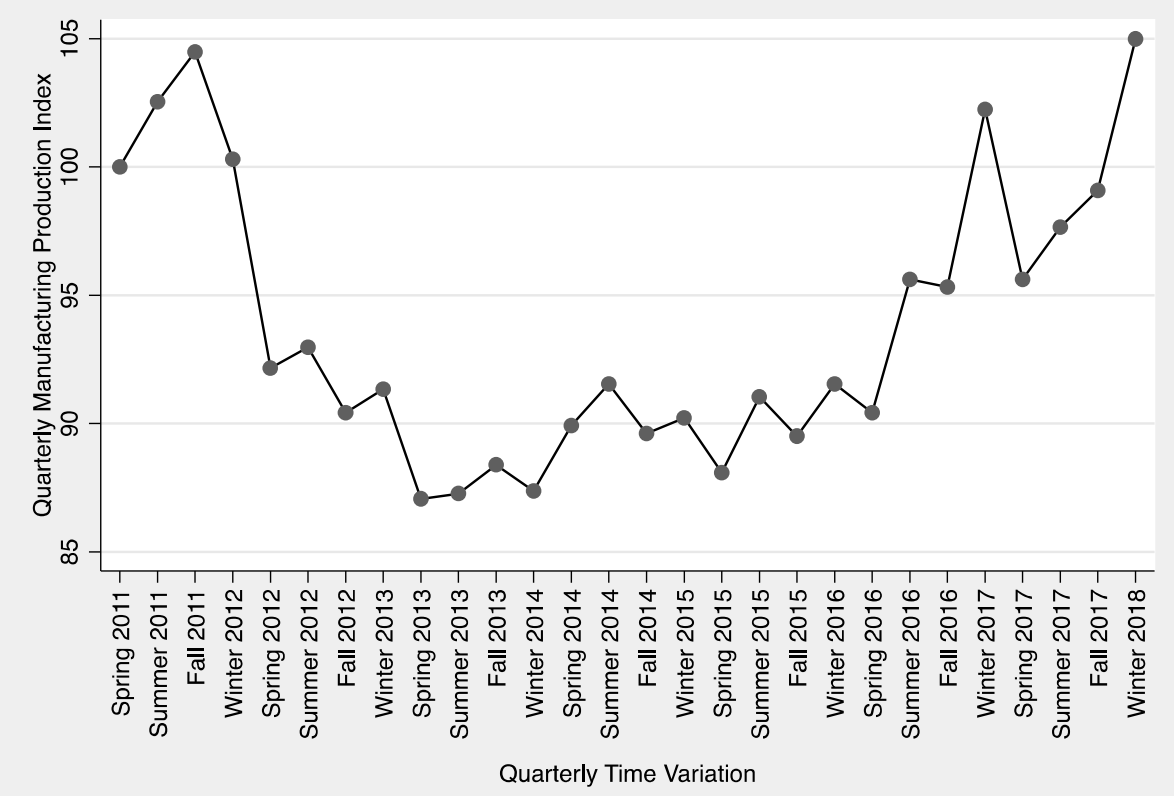

Source: Statistical Center of Iran (2019c) and authors' normalization.

Figure 4: Sector-specific production index for mining sector

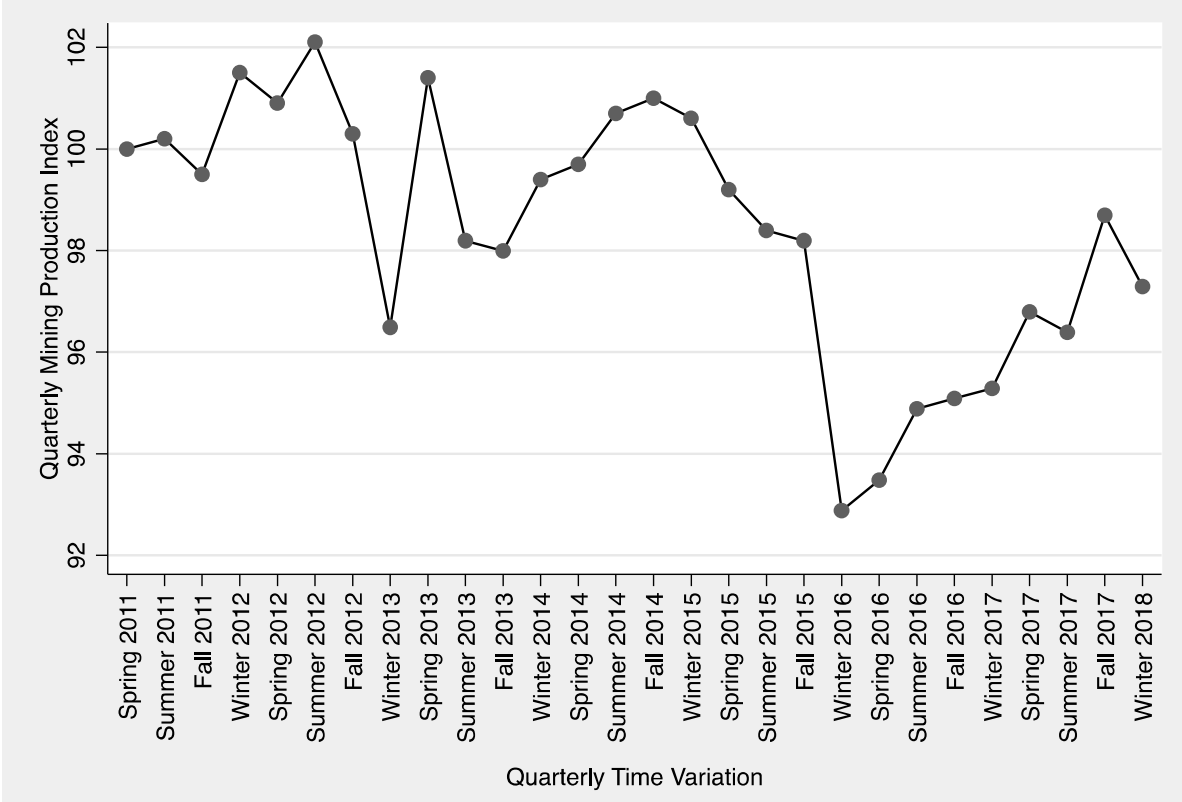

Source: Statistical Center of Iran (2019c) and authors' normalization. 
Figure 5: Sector-specific production index for agriculture sector

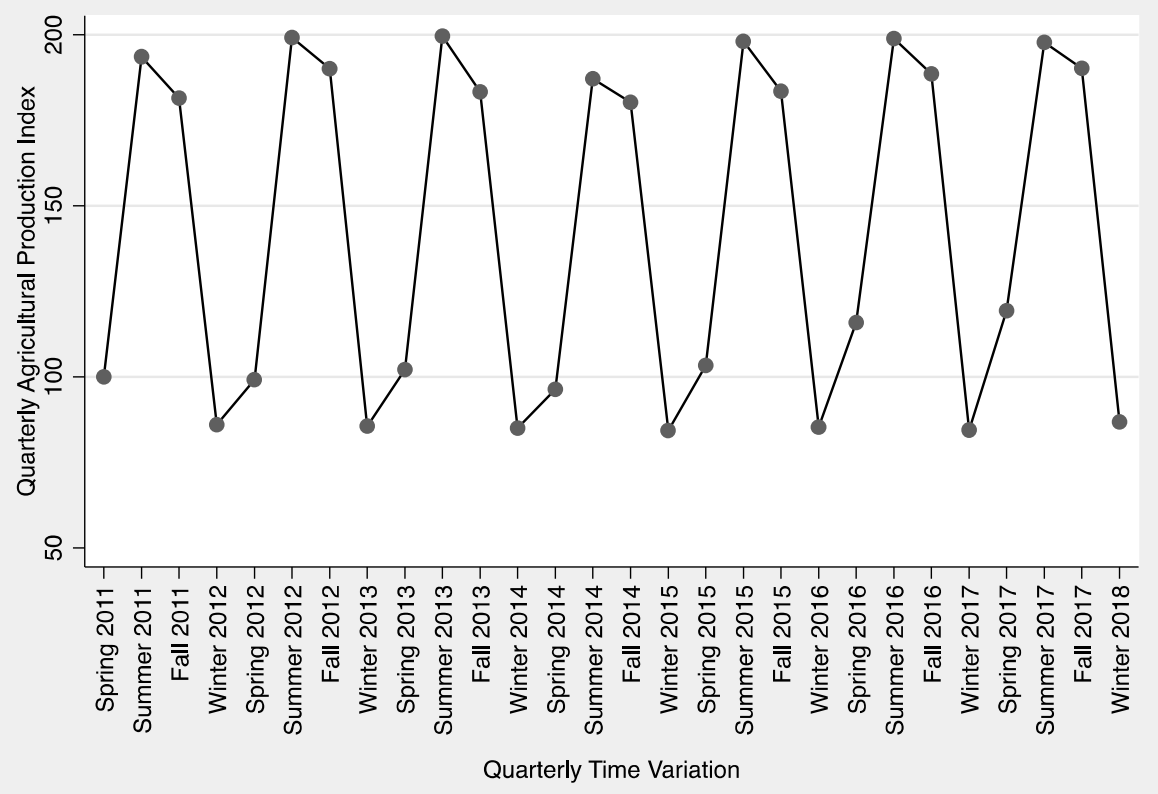

Source: Statistical Center of Iran (2019c) and authors' normalization.

Figure 6: Distributions of industry-specific growth rate of exports, before and after the JCPOA
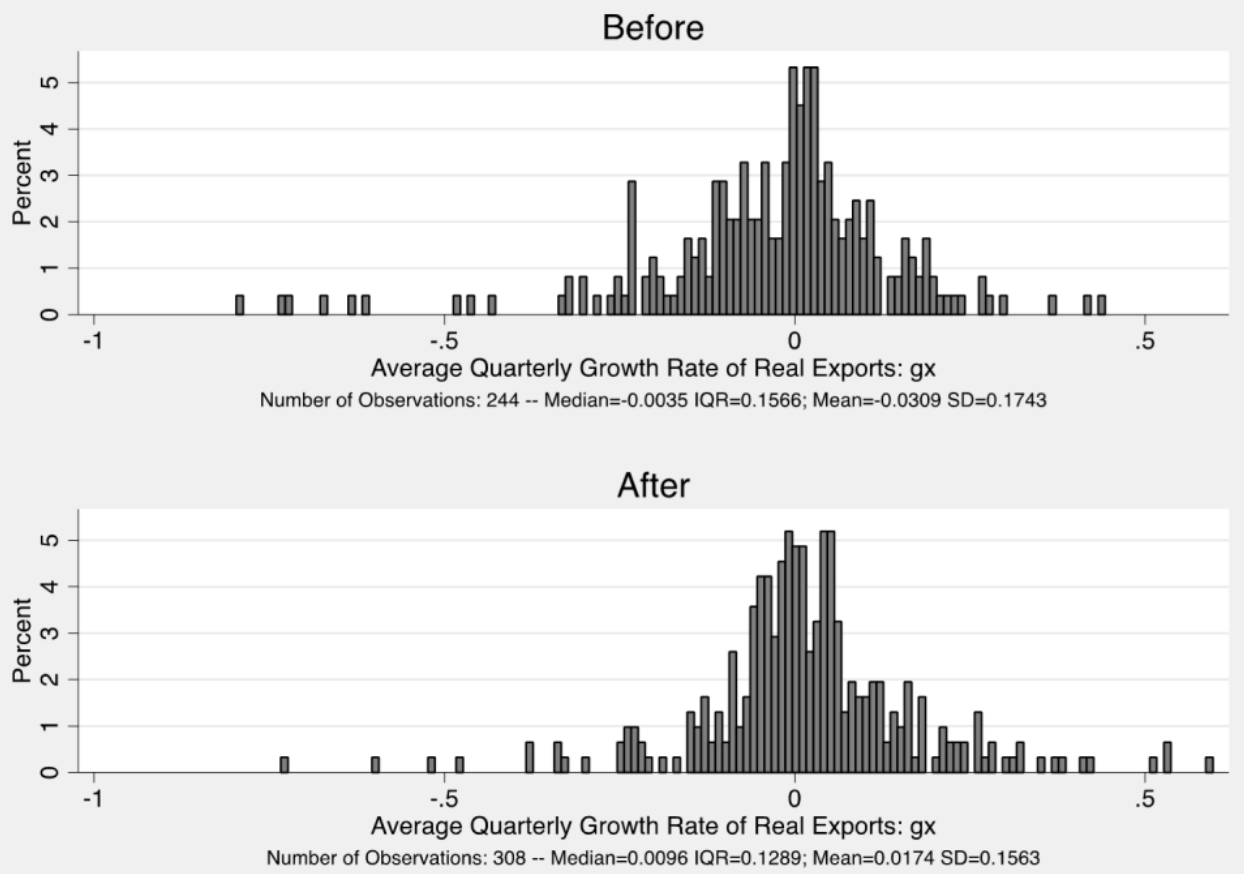

Source: Statistical Center of Iran (2019a) and authors' computation. 


\section{References}

Abrahamian, Ervand. A history of modern Iran-revised and updated. Cambridge University Press, 2018.

Aditya, Anwesha, and Rajat Acharyya. "Trade liberalization and export diversification." International Review of Economics \& Finance 39 (2015): 390-410.

Afesorgbor, Sylvanus Kwaku. "The impact of economic sanctions on international trade: How do threatened sanctions compare with imposed sanctions?" European Journal of Political Economy 56 (2019): 11-26.

Arellano, Manuel, and Stephen Bond. "Some tests of specification for panel data: Monte Carlo evidence and an application to employment equations." The Review of Economic Studies 58, No. 2 (1991): 277-297.

Arellano, Manuel, and Olympia Bover. "Another look at the instrumental variable estimation of errorcomponents models." Journal of Econometrics 68, No. 1 (1995): 29-51.

Axworthy, Michael. Revolutionary Iran: a history of the Islamic republic. Oxford University Press, 2013.

Blomberg, S. Brock, and Gregory D. Hess. "How much does violence tax trade?" The Review of Economics and Statistics 88, no. 4 (2006): 599-612.

Blundell, Richard, and Stephen Bond. "Initial conditions and moment restrictions in dynamic panel data models." Journal of Econometrics 87, No. 1 (1998): 115-143.

Bruegel. "Real effective exchange rates for 178 countries: A new database". 2019. Accessed July 10th, 2019. https://bruegel.org/publications/datasets/real-effective-exchange-rates-for-178countries-a-new-database/

Cali, Massimiliano, and Dirk Willem Te Velde. "Does aid for trade really improve trade performance?" World Development 39, no. 5 (2011): 725-740.

Caruso, Raul. "The impact of international economic sanctions on trade: An empirical analysis." Peace Economics, Peace Science and Public Policy 9, no. 2 (2003).

C.B.I.: Central Bank of the Islamic Republic of Iran. "Economic Time Series Database." Accessed February 15th, 2019. https://tsd.cbi.ir

Council on Foreign Relations. "What is the Status of the Iran Nuclear Agreement?" Accessed October 20th, 2019. https://www.cfr.org/backgrounder/what-status-iran-nuclear-agreement

Crozet, Matthieu, and Julian Hinz. "Friendly Fire: The Trade Impact of the Russia Sanctions and Counter-Sanctions." Economic Policy, Forthcoming (2020).

Darvas, Zsolt. Real effective exchange rates for 178 countries: A new database. Working Paper 2012/06, Bruegel, 2012

De Sousa, José, Daniel Mirza, and Thierry Verdier. "Terror networks and trade: Does the neighbor hurt?" European Economic Review 107 (2018): 27-56.

Devarajan, Shanta, and Lili Mottaghi. Economic implications of lifting sanctions on Iran. Middle East and North Africa Quarterly Economic Brief, World Bank, 2015

Didier, Laurent. "The impact of conflict on trade in services: A sector-level analysis." Comparative Economic Studies 62 (2020): 34-48.

Esfahani, Mohammad, and Ehsan Rasoulinezhad. "Iran's trade policy of Asianization and deEuropeanization under sanctions." Journal of Economic Studies (2017).

Farzanegan, Mohammad Reza, Mohammad Mohammadi Khabbazan, and Hossein Sadeghi. "Effects of oil sanctions on Iran's economy and household welfare: new evidence from a C.G.E. model." In Economic welfare and inequality in Iran, pp. 185-211. Palgrave Macmillan: New York, 2016.

Felbermayr, Gabriel, Constantinos Syropoulos, Erdal Yalcin, and Yoto V. Yotov. On the effects of sanctions on trade and welfare: New evidence based on structural gravity and a new database. No. 2131. Kiel Institute for the World Economy (IfW), (2019). 
Gharibnavaz, Mohammad Reza, and Robert Waschik. "A computable general equilibrium model of international sanctions in Iran." The World Economy 41, no. 1 (2018): 287-307.

Ghattas, Kim. Black wave: Saudi Arabia, Iran, and the forty-year rivalry that unraveled culture, religion, and collective memory in the Middle East. Henry Holt and Company, 2020.

Giri, Rahul, Saad N. Quayyum, and Rujun Yin. Understanding export diversification: Key drivers and policy implications. International Monetary Fund, 2019.

Glick, Reuven, and Alan M. Taylor. "Collateral damage: Trade disruption and the economic impact of war." The Review of Economics and Statistics 92, no. 1 (2010): 102-127.

Gnangnon, Sena Kimm. "Multilateral trade liberalisation helps promote export product diversification: Trade tensions damage the prospects of the poorest economies." Economic Affairs 39, no. 3 (2019): 363-380.

Goldstein, Morris, and Mohsin S. Khan. "Income and price effects in foreign trade." Handbook of International Economics 2 (1985): 1041-1105.

Haidar, Jamal Ibrahim. "Sanctions and export deflection: evidence from Iran." Economic Policy 32, no. 90 (2017): 319-355.

Hegre, Håvard, John R. Oneal, and Bruce Russett. "Trade does promote peace: New simultaneous estimates of the reciprocal effects of trade and conflict." Journal of Peace Research 47, no. 6 (2010): 763-774.

Ianchovichina, Elena, Shantayanan Devarajan, and Csilla Lakatos. Lifting economic sanctions on Iran: global effects and strategic responses. The World Bank, 2016.

Maloney, Suzanne. Iran's political economy since the revolution. Cambridge University Press, 2015.

Martin, Philippe, Thierry Mayer, and Mathias Thoenig. "Make trade not war?" The Review of Economic Studies 75, no. 3 (2008): 865-900.

"The geography of conflicts and regional trade agreements." American Economic Journal: Macroeconomics 4, no. 4 (2012): 1-35.

Mottaghi, Lili. Estimating the impacts of lifting sanctions on trade in Iran. World Bank. 2015

NBSC: National Bureau of Statistics of China. "Statistical Data: Quarterly Data for Gross Domestic Product (at Constant Prices)". Accessed July 31st, 2020. http://www.stats.gov.cn/english/

Nenci, Silvia. "Tariff liberalisation and the growth of world trade: A comparative historical analysis of the multilateral trading system." The World Economy 34, no. 10 (2011): 1809-1835.

OPEC: Organization of the Petroleum Exporting Countries. "Table 5.3: World crude oil exports by country". Accessed October 25th, 2019a. https://asb.opec.org/index.php/data-download "Table 2.5: OPEC members' value of petroleum exports". Accessed October 25th, 2019b. https://asb.opec.org/index.php/data-download

Osakwe, Patrick N., Amelia U. Santos-Paulino, and Berna Dogan. Trade dependence, liberalization and exports diversification in developing countries. United Nations Conference on Trade and Development, 2018

Pham, Cong S., and Chris Doucouliagos. An Injury to one is an injury to all: Terrorism's spillover effects on bilateral trade. No. 10859. I.Z.A. Discussion Papers, 2017.

Qureshi, Mahvash Saeed. "Trade and thy neighbor's war." Journal of Development Economics 105 (2013): 178-195.

Ratnaike, Yasanji C. "Is there an empirical link between trade liberalisation and export performance?" Economics Letters117, no. 1 (2012): 375-378.

Reuters. "Interim nuclear agreement between Iran and six powers". 2013. Accessed October 25th, 2019. https://www.reuters.com/article/us-iran-nuclear-agreement-textidUSBRE9AN0BQ20131124

"West, Iran activate landmark nuclear deal". 2014. Accessed October 25th, 2019. https://www.reuters.com/article/us-iran-nuclear/west-iran-activate-landmark-nuclear-dealidUSBREA0J00420140120

Saikal, Amin. Iran Rising: The Survival and Future of the Islamic Republic. Princeton University Press, 2019. 
Santos-Paulino, Amelia U. "Trade liberalisation and export performance in selected developing countries." Journal of Development Studies 39, no. 1 (2002): 140-164.

"Aid and trade sustainability under liberalisation in least developed countries." World Economy 30, no. 6 (2007): 972-998.

Santos-Paulino, Amelia, and Anthony P. Thirlwall. "The impact of trade liberalisation on exports, imports and the balance of payments of developing countries." The Economic Journal 114, no. 493 (2004): F50-F72.

S.C.I.: Iran Statistical Center. "Data and statistical information: commerce and business - exports and

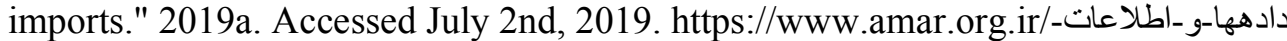
5561691\#"--

"Statistical tables: price indexes - producer price index." 2019b. Accessed July 2nd, 2019.

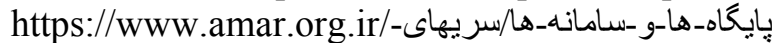

زمانى/agentType/ViewType/PropertyTypeID/2033

"Data and statistical information: national and regional accounts - quarterly production index for manufacturing, mining, and agriculture." 2019c. Accessed July 2nd, 2019c.

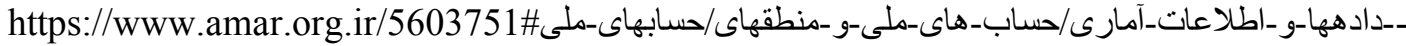

Seitz, Michael, Alexander Tarasov, and Roman Zakharenko. "Trade costs, conflicts, and defense spending." Journal of International Economics 95, no. 2 (2015): 305-318.

U.N.: The United Nations. "U.N. Comtrade Database". 2020. Accessed July 10th, 2020. https://comtrade.un.org

U.N. Security Council. "Resolution 2231 (2015) on Iran Nuclear Issue". 2015. Accessed October 20th, 2019. https://www.un.org/securitycouncil/content/2231/background

"Resolution 1747 (2007)". 2007. Accessed October 20th, 2019. https://undocs.org/S/RES/1747(2007)

"Resolution 1929 (2010)". 2010. Accessed October 20th, 2019. http://unscr.com/en/resolutions/doc/1929

UNIDO: The United Nations Industrial Development Organization. 2020. "INDSTAT2 2020, ISIC Revision 3". Accessed July 15th, 2020. https://stat.unido.org

U.S. Department of State. "Iran Sanctions". Accessed October 20th, 2019. https://www.state.gov/iransanctions/

U.S. Department of the Treasury. "Additional Designation of Two Entities Pursuant to Executive Order 13224". Federal Register 72, no. 225 (2007)

Vicard, Vincent. "Trade, conflict, and political integration: Explaining the heterogeneity of regional trade agreements." European Economic Review 56, no. 1 (2012): 54-71.

World Bank. "Exports of goods and services (constant 2010 US\$)". Accessed October 25th, 2019a. https://data.worldbank.org/indicator/NE.EXP.GNFS.KD

"GDP, PPP (constant 2011 international \$)". Accessed October 25, $2019 \mathrm{~b}$. https://data.worldbank.org/indicator/NY.GDP.MKTP.PP.KD

"Imports of goods and services (constant 2010 US\$)". Accessed October 25th, 2019c. https://data.worldbank.org/indicator/NE.IMP.GNFS.KD

Yang, Jiawen, Hossein Askari, John Forrer, and Hildy Teegen. "U.S. economic sanctions: An empirical study." The International Trade Journal 18, no. 1 (2004): 23-62. 


\section{Appendix: Sanctions, JCPOA, and Iran's Economy}

In this appendix, we briefly survey the political and economic developments that led to the Joint Plan of Action (henceforth, JPOA), reached on November 2013, and the Joint Comprehensive Plan of Action (henceforth, JCPOA), reached on July 2015.

Nuclear Activities and International Sanctions-Iran started its nuclear program in the 1970s. The U.S. and other European countries were at first supportive of Iran's nuclear ambitions. In fact, with the help of German contractors, the construction of two nuclear reactors were already at advanced stages on the eve of the revolution in February 1979. Following the revolution, however, Iran halted its nuclear program. Reportedly, the leadership had some doubt about pursuing nuclear technology. But, ultimately, Iran restarted its nuclear program as part of its post-war development efforts. By January 1995, Iran finalized a deal with Russian contractors to renew the work on the unfinished nuclear reactors. Ever since then, Iran has continued its nuclear activities in varying capacities. Some aspects of the renewed nuclear activities have led to increased tensions between Iran, the U.S., the E.U., and the U.N. Following a report by International Atomic Energy Agency in 2005, declaring that Iran was not in compliance with the Nuclear Non-Proliferation Treaty Safeguard Agreements, the U.N. Security Council asked Iran to suspend uranium enrichment. When Iran declined to act upon this request, the U.N. Security Council imposed the first of a series of sanctions against Iran, starting from 2006 (Axworthy, 2013; pp. 380-386).

The U.N. Security Council imposed the aforementioned sanctions under three resolutions: UNSC Res. No. 1696 (July 31 $1^{\text {st }}$, 2006), UNSC Res. No. 1737 (December 23 ${ }^{\text {rd }}, 2006$ ), and UNSC Res. No. 1747 (March 24 $\left.4^{\text {th }}, 2007\right)$. The ultimate goal of these measures was to "constrain Iran's development of sensitive technologies in support of its nuclear and missile programs" (U.N. Security Council, 2007). These measures mainly targeted individuals and entities that were associated with Iran's nuclear program to prevent undue harm to Iran's economy (Maloney, 2015; pp. 464-473). Nevertheless, they were imposed when Iran was already under mounting pressure from the U.S., resulting from an array of old and new sanctions. For example, a number of Iranian banks were already being considered as "additional entities" under the sanctions that were outlined in Executive Order No. 13244 on blocking the property and 
prohibiting transactions with individuals or entities who support terrorism (U.S. Department of the Treasury, 2007).

Iran continued with its nuclear program. In return, the U.S., the E.U., and the U.N. imposed more sanctions. Preceded by the UNSC Res. No. 1803 (March 3 ${ }^{\text {rd }}$, 2008), the U.N. Security Council imposed further sanctions against Iran under UNSC Res. No. 1929 (June $\left.9^{\text {th }}, 2010\right)$, targeting 1.) additional individuals and entities involved in Iran's nuclear or ballistic missile program, 2.) entities associated with the Islamic Revolutionary Guard Corps (henceforth, IRGC) including Khatam Al-Anbiya Construction Headquarter, an important IRGC entity involved in large-scale construction projects and engineering activities, and 3.) entities associated with Iran Shipping Lines (U.N. Security Council, 2010). In the same year, the U.S. and the E.U. imposed new sanctions, targeting Iran's petroleum and energy sectors. In 2011, the U.S. imposed further sanctions, targeting Iran's petrochemical industry, and the U.K. significantly delimited its financial relations with Iran, including with the Central Bank of Iran (henceforth, C.B.I.). Also, between 2011 and 2013, the U.S. and the E.U. imposed further sanctions against C.B.I. along with an array of new sanctions, targeting Iran's crude oil exports and it access to European-based insurance and financial services (Maloney, 2015; pp. 464-473). Aggregate Economic Effects of Sanctions - It is empirically challenging to disentangle the aggregate effects of mounting international sanctions (between 2006 and 2013) from the aggregate effects of fiscal, monetary, and commercial policies that were motivated by the populist agenda of Ahmadinejad's administration (between 2005 and 2013). Nevertheless, it is evident that Iran's real gross domestic products measured by purchasing power parity (henceforth, PPP GDP) plunged significantly starting from 2011, during which international sanctions were already intensified (World Bank, 2019b). ${ }^{1}$ See Figure A1 in this appendix for more detail. Iran's PPP GDP remains at low levels until 2013. In fact, Iran's real PPP GDP in 2013 (1.27 trillion international dollars) is almost equal to its real PPP GDP in 2007 (1.25 trillion

\footnotetext{
${ }^{1}$ The World Bank's International Comparison Program measures PPP GDP using international dollars. The purchasing power of one unit of international dollar over Iran's GDP is equal to the purchasing power of one US dollar over the US GDP. To account for inflation, the World Bank considers the purchasing power of international dollars in 2011. For more, see World Bank (2019b).
} 
international dollars), and it does not revert to its post-war trend until $2017 .^{2}$ This interruption is also evident when we compare the median growth rate of PPP GDP between 2005 and 2013 (1.8\%) with the median growth rates in previous post-war administrations: 3.6\% during Khatami's administration (19972005) and 2.2\% during Hashemi Rafsanjani's administration (1990-1997). See Figure A2 in the appendix for more detail.

The JCPOA Agreement-By the end of the Ahmadinejad's administration, the economic consequences of international sanctions were visibly clear to the political elite in Iran; their awareness was frequently displayed during presidential campaign in $2013 .{ }^{3}$ Also, international sanctions had become an important concern for the majority of voters in Iran, and presidential candidates were aware of that. Ultimately, supported by a wide coalition of reformist, moderate, and centrist groups, Rouhani won the presidential election "with the main conservative candidate receiving a mere 11 percent of the vote" (Abrahamian, 2018; p. 202).

Following a series of secret negotiations between Iran and the U.S. that had already started in 2012 (Ghattas, 2020, p. 297), Rouhani's administration quickly set out to settle the tension between Iran, the U.S., the E.U., and the U.N. In November 2013, his administration finalized an interim agreement with China, France, Germany, Russia, the U.K., and the U.S. The interim agreement, the JPOA, set the stage for a comprehensive agreement, the JCPOA, which was finalized in July 2015. As mentioned in the manuscript, the JCPOA agreement offered significant sanctions relief. But it was short-lived. Nonetheless, it led to a significant recovery in Iran's G.D.P. (Figure A1) and exports (Figures A3-A5).

\footnotetext{
${ }^{2}$ Though the trends are similar, PPP GDP in constant prices at a given year is significantly greater than GDP in constant prices for a developing country like Iran. For the data from 1990 to 2017, the World Bank considers Iran's PPP GDP at any given year to be about 2.75 times larger than its real GDP in the same year to account for the differences in price levels between Iran and the US. For example, in constant 2011 international dollars, Iran's PPP GDP was about 641 billion international dollars at the beginning of Hashemi Rafsanjani's administration in 1990. Ignoring the purchasing power parity, Iran's real GDP in 1990 is only about 233 billion dollars (in constant 2010 US dollars). Iran's PPP GDP, measured again in constant 2011 international dollars, increases to 1.541 trillion international dollars by the end of Rouhani's first term in office in 2017. Ignoring the purchasing power parity, Iran's real GDP in 2017 is only about 561 billion dollars (in constant 2010 US dollars).

${ }^{3}$ For example, in a widely watched televised debate on foreign policy, Hassan Rouhani, a presidential candidate and a former nuclear negotiator, publicly questioned "the utility of spinning centrifuges when factories are idled" (Maloney, 2015; p. 492).
} 
Figure A1: Iran's PPP GDP

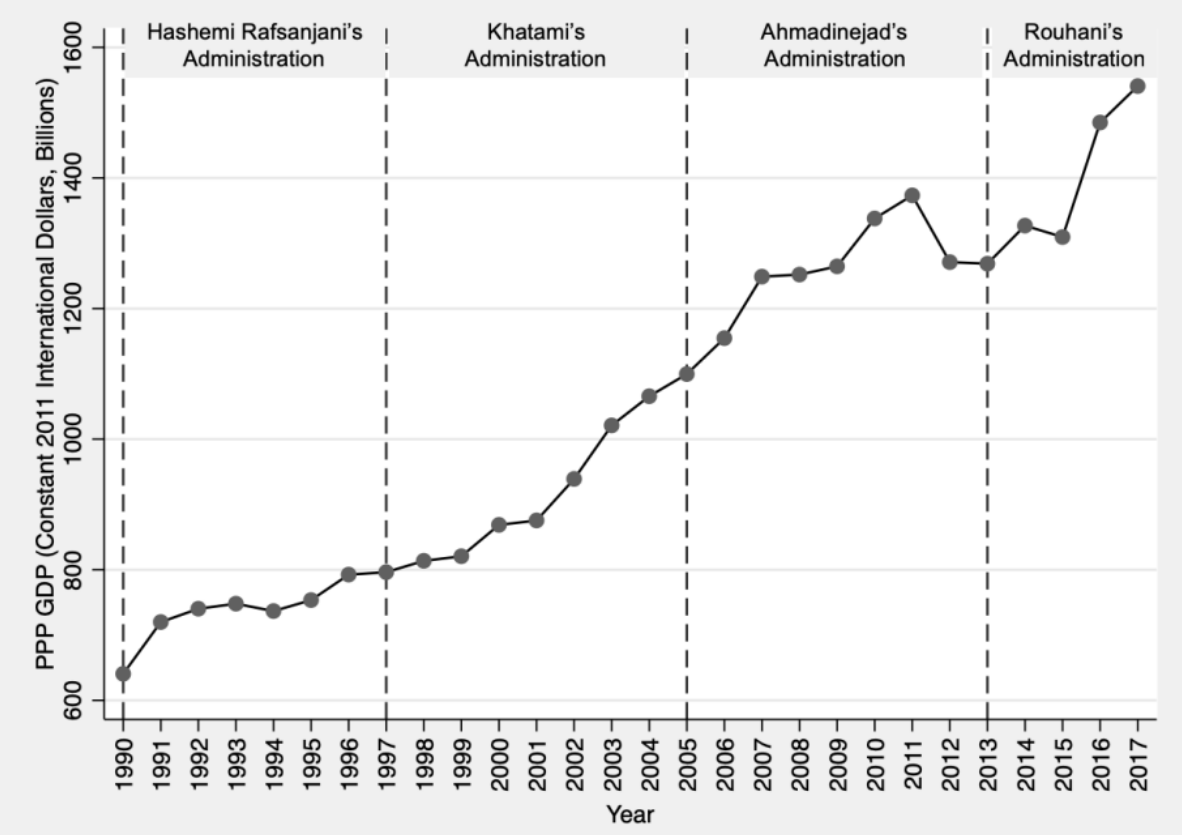

Source: World Bank (2019b)

Figure A2: Growth rate of Iran's PPP GDP

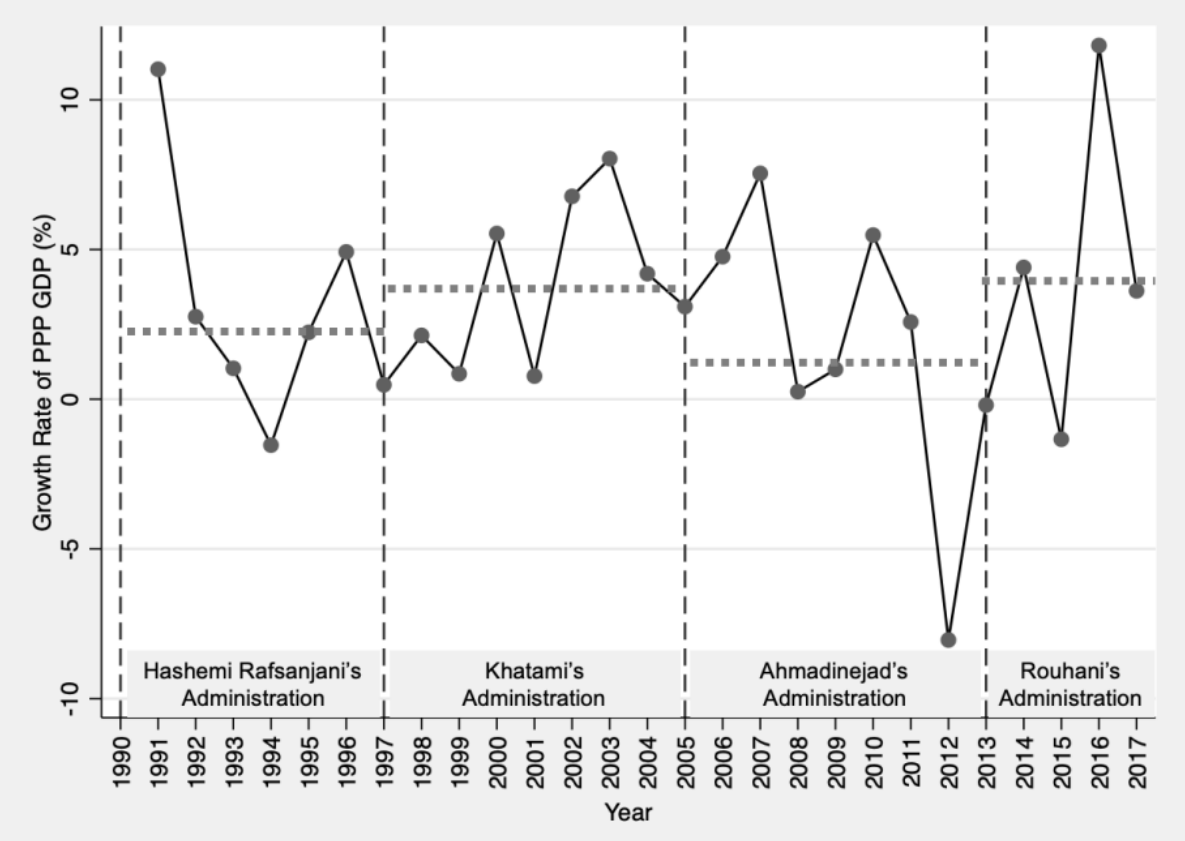

Source: World Bank (2019b) and authors' computation 
Figure A3: Aggregate exports and imports in constant 2010 U.S. dollars

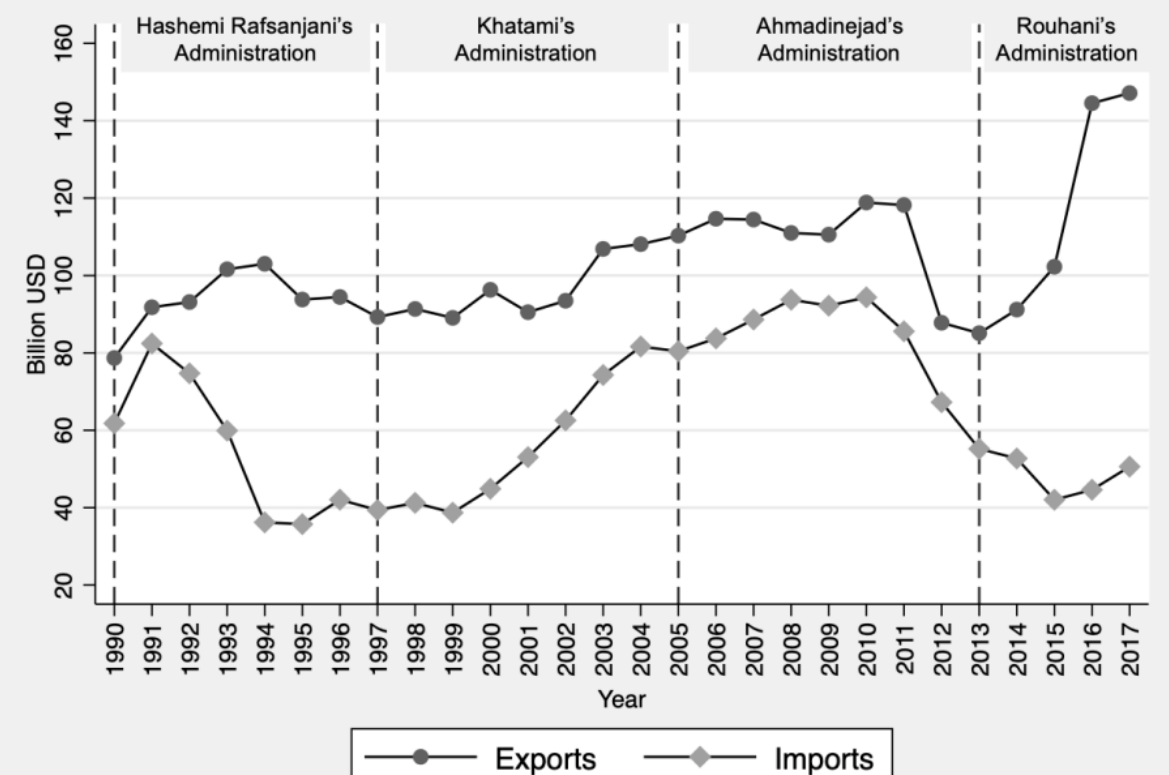

Note: Aggregate exports and imports are measured using constant 2010 US dollars.

Sources: World Bank (2019a and 2019c)

Figure A4: Quantity of crude oil exports (mbpd)

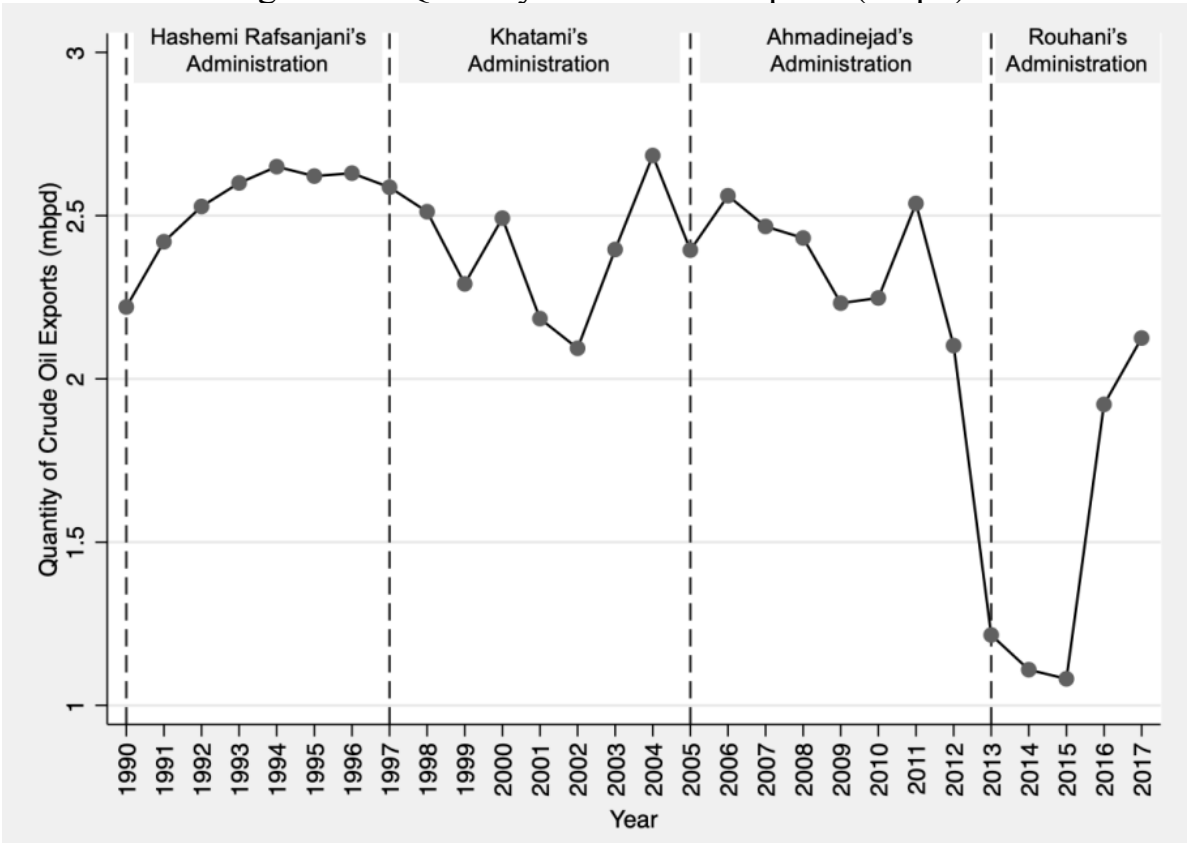

Source: Organization of the Petroleum Exporting Countries (2019a) 
Figure A5: Value of oil exports in current U.S. dollar

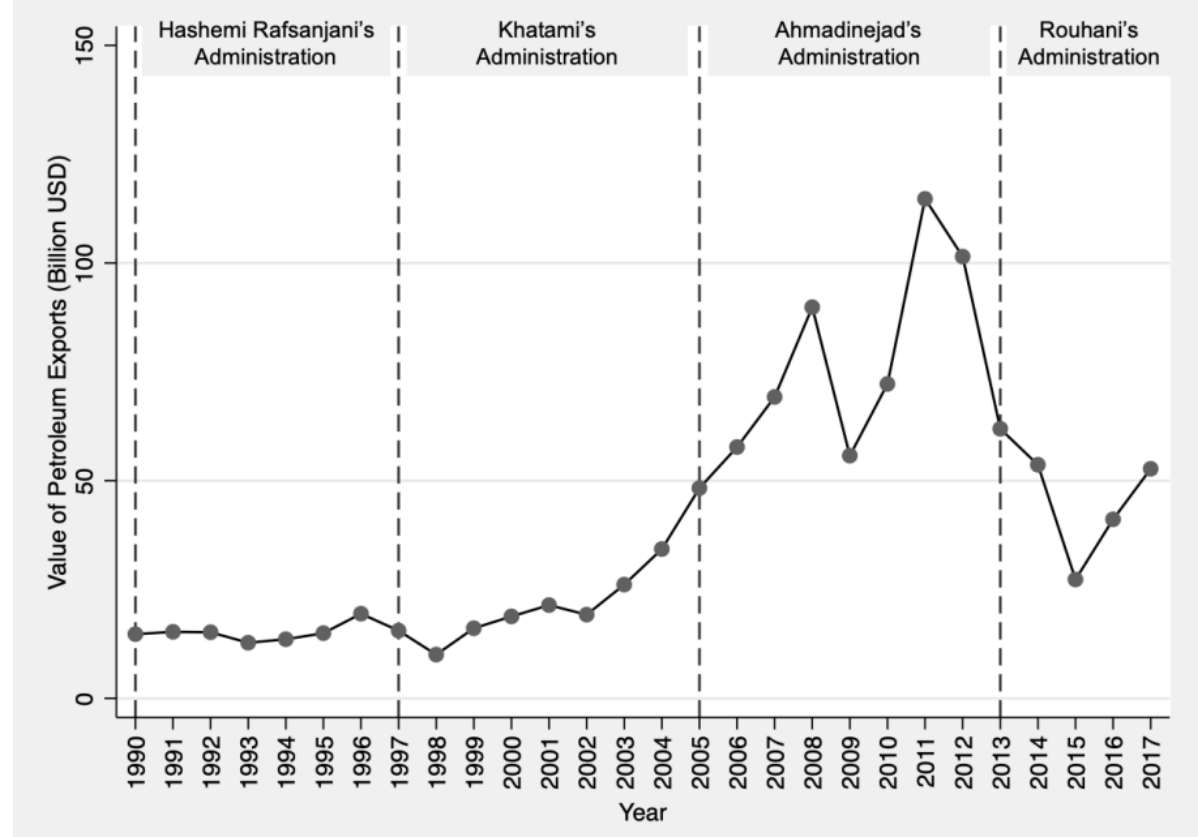

Source: Organization of the Petroleum Exporting Countries (2019b) 